\title{
MAPK signaling in neurodegeneration: influences of flavonoids and of nitric oxide
}

\author{
Hagen Schroeter ${ }^{\mathrm{a}, \mathrm{b}}$, Clinton Boyd ${ }^{\mathrm{b}}$, Jeremy P.E. Spencer ${ }^{\mathrm{a}}$, Robert J. Williams ${ }^{\mathrm{a}}$, \\ Enrique Cadenas ${ }^{\mathrm{b}}$, Catherine Rice-Evans ${ }^{\mathrm{a}}$, \\ a Antioxidant Research Group, Wolfson Centre for Age-Related Diseases and Centre for Neuroscience Research, Guy's, King's and St. Thomas's \\ School of Biomedical Sciences, King's College, Guy's Campus, Hodgkin Bldg., 3rd Floor, London SE1 9RT, UK \\ ${ }^{\mathrm{b}}$ Department for Molecular Pharmacology and Toxicology, School of Pharmacy, University of Southern California, Los Angeles, CA 90033, USA
}

Received 5 September 2001; received in revised form 21 February 2002; accepted 7 March 2002

\begin{abstract}
Oxidative and nitrosative stress is increasingly associated with the pathology of neurodegeneration and aging. The molecular mechanisms underlying oxidative/nitrosative stress-induced neuronal damage are emerging and appear to involve a mode of death in which mitogen-activated protein kinase (MAPK) signaling pathways are strongly implicated. Thus, attention is turning towards the modulation of intracellular signaling as a therapeutic approach against neurodegeneration. Both endogenous and dietary agents have been suggested as potent modulators of intracellular signal transduction, e.g. nitric oxide and flavonoids, respectively. This review addresses recent findings on the biological effects of flavonoids and nitric oxide in neurodegeneration and aims to elucidate the rationale for their prospective use as modulators of cellular signal transduction.
\end{abstract}

(C) 2002 Elsevier Science Inc. All rights reserved.

Keywords: Apoptosis; Oxidative stress; Neuron; Flavonoids; MAP kinase; JNK; ERK; Epicatechin; Nitric oxide; Mitochondria; Redox status; Polyphenols

Abbreviations: AKT, serine/threonine kinase (also known as protein kinase B); AP-1, activator protein-1; Apaf-1, apoptosis protease activating factor-1; ASK1, apoptosis signal-regulating kinase-1; Bad, Bcl-2/BclX $\mathrm{L}^{-}$ associated death promoting protein; Bax, pro-apoptotic protein of the Bcl-2 family; Bcl-2, B-cell lymphoma 2: protein with anti-apoptotic properties; $\mathrm{BclX}_{\mathrm{L}}$, long form of Bclx: anti-apoptotic protein of the Bcl-2 family; Caspase, cysteinyl aspartic acid-protease; c-Jun, mammalian equivalent of Jun: part of the AP-1 transcription complex; CREB, cAMP response element binding protein; DIABLO/smac, mitochondria-related pro-apoptotic protein: inhibits XIAP; ERK1/2, extracellular signal-related kinase; Fas, CD95: member of the TNF receptor family; GSHST, glutathione $S$ transferase; JNK, c-Jun amino-terminal kinase; MAPK, mitogen-activated protein kinase; MAPKK, MAPK kinase; MAPKKK, MAPKK kinase; MEK1/2, ERK1/2-specific MAPKK; MKK4/7, JNK-specific MAPKK; MSK1, mitogen- and stress-activated kinase-1; NF- $\mathrm{BB}$, nuclear factor of immunoglobulin $\mathrm{k}$ locus in $\mathrm{B}$-cells; $\mathrm{ONOO}^{-}$, peroxynitrite anion; $p 53$, pro-apoptotic tumor suppressor gene product; PI3-kinase, phosphoinositol 3-kinase; Ras, small G-protein; RNS, reactive nitrogen species; ROS, reactive oxygen species; RSK, pp90 ribosomal S6 kinase; SAPK, stressactivated protein kinase; XIAP, X-linked inhibitor of apoptosis: inhibits the activation of caspase- 9

* Corresponding author. Tel.: +44-20-7848-6141; fax: +44-20-7848-6143.

E-mail address: catherine.rice-evans@kcl.ac.uk (C. Rice-Evans).

\section{Oxidative/nitrosative stress}

The pathology of neurodegeneration and aging is increasingly associated with oxidative and nitrosative stress mediated by reactive oxygen species (ROS) and reactive nitrogen species (RNS) [64,77], thus implicating the use of antioxidants as potentially beneficial strategies. The redox state of the cell is the net balance between the steady-state levels of ROS and RNS and the cellular antioxidant systems. A key indicator of this balance is the ratio GSH/GSSG, or more accurately, the GSH redox potential. The GSH/GSSG pool is dynamic, undergoing reversible oxidation-reduction reactions with ROS and RNS, antioxidant systems and protein thiols. Furthermore, it appears that cells become more oxidized during the progression of the life cycle from the proliferative state ( -230 to $260 \mathrm{mV}$ ), through cell cycle arrest and differentiation $(-200 \mathrm{mV})$ to apoptosis $(-150 \mathrm{mV})$. The latter trend is paralleled by a progressive increase in the cellular quasi steady-state level of $\mathrm{H}_{2} \mathrm{O}_{2}$, with expected changes in the subcellular $\mathrm{H}_{2} \mathrm{O}_{2}$ gradients across membranebound organelles $[8,9]$ : a proliferative state can be observed in Jurkat $\mathrm{T}$ cells at $[2]_{\mathrm{ss}}<0.7 \mu \mathrm{M}$; at slightly higher levels $(1-3 \mu \mathrm{M})$ cells enter the apoptotic process and, at even higher levels $(>3 \mu \mathrm{M})$ cells undergo necrosis (Fig. 1). 


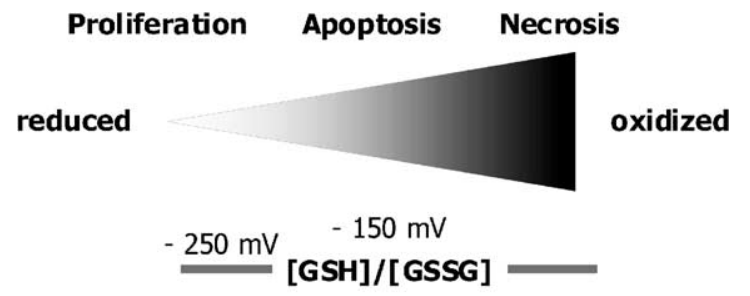

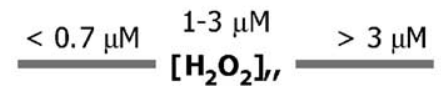

Fig. 1. The cellular redox state, glutathione, and hydrogen peroxide levels. In proliferating cells, the glutathione redox status is approximately $-250 \mathrm{mV}$, whereas, apoptotic cells have a redox status of approximately $-150 \mathrm{mV}$. The steady-state level of hydrogen peroxide in proliferating cells was calculated to be below $0.7 \mu \mathrm{M}$ increasing to over $3 \mu \mathrm{M}$ under conditions of necrosis. The glutathione redox potential values and the hydrogen peroxide steady-state levels appear to represent a continuum from a reduced state to an oxidized state as cell progress from cell division to cell death.

Taken together oxidative/nitrosative stress is the shift of the redox status of a cell towards oxidation resulting in the impairment of cellular function and damage to essential biomolecules. The cellular responses to oxidative insults range from survival, repair of damage and the enhancement of cellular antioxidant defences, on the one hand, to cellular senescence and apoptotic or necrotic cell death, at the other extreme. This places intracellular signaling pathways in a key position to sense, interpret, and ultimately determine the outcome following a shift in the redox status, or an oxidative insult. The differential sensitivity of cell types to oxidative and nitrosative stress is a function of the steady-state levels of the oxidant, its chemical reactivity, and the general cellular

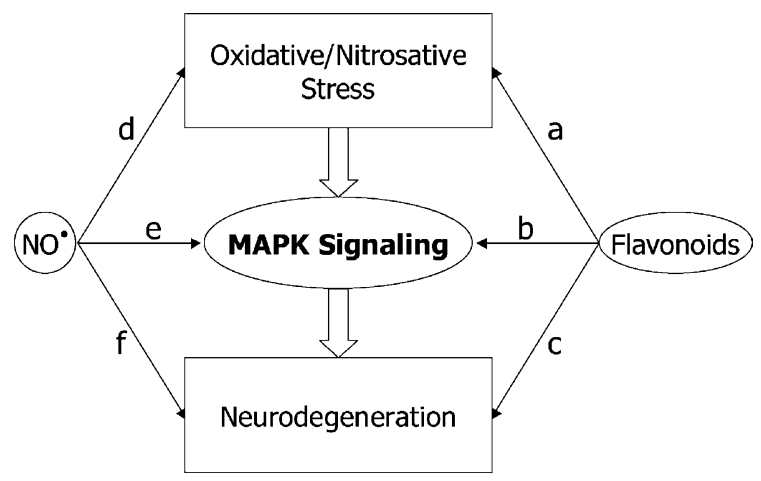

Fig. 2. MAPK signalling in neurodegeneration: influences of flavonoids and nitric oxide. The scheme demonstrates potential sites of action for flavonoids and nitric oxide with respect to their proposed modulatory effects in neurodegeneration as addressed in this review. Flavonoids might (a) directly influence oxidative/nitrosative stress due to their hydrogen-donating properties, (b) specifically act within MAPK signaling cascades, or (c) influence neurodegeneration by other means, for example modulation of GABA-receptor properties or mitochondrial function. Nitric oxide may (d) directly influence the intracellular redox-state, (e) modulate MAPK signaling, (f) alter other cellular functions including mitochondrial function or neurotransmitter release. environment as evaluated by the redox-sensitive components of intracellular signal transduction. These parameters are taken into consideration in this review when addressing the differential effects of dietary flavonoids and the endogenous free radical nitric oxide $\left(\mathrm{NO}^{\bullet}\right)$ on signal transduction pathways involving mitogen-activated protein kinase (MAPK), and their implications for neurodegeneration (Fig. 2).

\section{Nitric oxide and the cellular redox state}

The differential sensitivity of cell types to a steady-state level of $\mathrm{NO}^{\bullet}$ is not simply a consequence of the amount of $\mathrm{NO}^{\bullet}$ produced, but more importantly, the nature of the RNS generated and the prevailing cellular environment. The interplay between several factors within the local microenvironment in which $\mathrm{NO}^{\bullet}$ is released is critical in determining which species are generated and whether a cytotoxic or cytostatic response is manifested physiologically. These factors include the cellular redox state, hydrophobicity of the local environment, presence of other reactive mediators, and the nature, bioavailability, and proximity of molecular targets [79].

The main reactions of $\mathrm{NO}^{\bullet}$ of biological interest and of potential significance for modulation of signal transduction pathways are (a) its reduction to $\mathrm{NO}^{-}$(nitroxide ion) (b) its oxidation to $\mathrm{NO}^{+}$(nitrosonium ion) and (c) radical-radical addition reactions [45]. The former follows general Eq. (1) and occurs with a variety of electron donors yielding the triplet-state $\mathrm{NO}^{-}$and the radical form of the donor. The oxidation of $\mathrm{NO}^{\bullet}$ to $\mathrm{NO}^{+}$requires strong oxidants, such as hydroxyl radical $\left(\mathrm{HO}^{\bullet}\right)$, nitrogen dioxide $\left(\mathrm{NO}_{2}\right)$, or peroxynitrite anion $\left(\mathrm{ONOO}^{-}\right)$. Within the cellular environment, $\mathrm{NO}^{+}$exists as a pool of nitrosating species or $\mathrm{NO}^{+}$-donors, such as $\mathrm{HNO}_{2}, \mathrm{~N}_{2} \mathrm{O}_{3}$, and $\mathrm{N}_{2} \mathrm{O}_{4}$. Nitrosating species can nitrosate nucleophiles, such as thiols, amines, and aromatics; hence, the overall effect is that of $\mathrm{NO}^{\bullet}$ addition reactions (nitrosation or nitrosylation) (Eq. (2)). The third type of reaction, the radical-radical addition includes mainly the reaction of $\mathrm{NO}^{\bullet}$ with superoxide anion, which occurs at a diffusion-controlled rate $\left(1.9 \times 10^{10} \mathrm{M} \mathrm{s}^{-1}\right)$ (Eq. (3)) and those with the above-mentioned radicals ( $\mathrm{HO}^{\bullet}$, $\mathrm{NO}_{2}, \mathrm{ONOO}^{-}$):

$\mathrm{NO} \bullet+\mathrm{AH}^{-} \rightarrow \mathrm{NO}^{-}+\mathrm{A}^{\bullet-}$,

$\bullet \mathrm{NO} \underset{\mathrm{HO}^{\bullet}, \mathrm{NO}_{2}^{\bullet}, \mathrm{ONOO}^{-}}{\stackrel{-1 \mathrm{e}^{-}}{\longrightarrow}} \mathrm{NO}^{+} \underset{\mathrm{RS}^{-}, \mathrm{NH}_{2}, \mathrm{Ar}-\mathrm{OH}}{\stackrel{\text { addition }}{\rightarrow}} \mathrm{RS}-\mathrm{N}=\mathrm{O}$

$\mathrm{NO}^{\bullet}+\mathrm{O}_{2}^{\bullet-} \rightarrow \mathrm{ONOO}^{-}$.

The $\mathrm{NO}^{\bullet}$ addition reactions (Eq. (2)) accomplished through intermediate formation of nitrosating species and leading to the formation of nitrosothiols are the subject of intensive research: it may be surmised that altering the redox status of critical thiols by $\mathrm{NO}^{\bullet}$ may serve a signaling function different from that originating from the reaction of 
$\mathrm{NO}^{\bullet}$ with the soluble gluanylate cyclase heme and leading to cGMP production. The reaction of $\mathrm{NO}^{\bullet}$ with iron ligands, however, may serve as a mechanism of reductive nitrosation, a process involving reduction of the metal by bound $\mathrm{NO}^{\bullet}$ (Eq. (4)) followed by nitrosation of a nucleophile (e.g. thiol) by the intermediate complex (Eq. (5)) [68]:

$\mathrm{NO}^{\bullet}+\mathrm{Fe}^{\mathrm{III}} \rightarrow\left[\mathrm{Fe}^{\mathrm{III}}-\mathrm{NO}^{\bullet} \Leftrightarrow \mathrm{Fe}^{\mathrm{II}}-\mathrm{NO}^{+}\right]$,

$\left[\mathrm{Fe}^{\mathrm{III}}-\mathrm{NO}^{\bullet} \Leftrightarrow \mathrm{Fe}^{\mathrm{II}}-\mathrm{NO}^{+}\right]+\mathrm{RSH} \rightarrow \mathrm{Fe}^{\mathrm{II}}+\mathrm{RS}-\mathrm{N}=\mathrm{O}$.

$\mathrm{NO}^{\bullet}$ and derived species can thus react reversibly or irreversibly with a vast array of cellular components, many of which are involved in cell signaling. Reactions mediated by peroxynitrite (e.g. carbonyl formation, nitration of tyrosine and tryptophan, oxidation of methionine, base deamination) typically lead to irreversible damage to proteins, lipids, and DNA and thus, loss of function. This fact, coupled with a biological half-life of seconds, would suggest that peroxynitrite chemistry is not amenable to cell signaling. However, there is a growing body of research arguing for such a role for peroxynitrite [79,119]. Post-translational modification of proteins by $S$-nitrosation, however, is an excellent candidate for cellular signaling. $S$-nitrosation is reversible process, allowing termination of the signal. To reiterate, $\mathrm{NO}^{\bullet}$ cannot react with thiols directly, but must proceed via a more redox active form, either a metal-NO ${ }^{\bullet}$ complex or by the formation of nitrosating species [68]. The process of $S$-nitrosation and trans-nitrosation is also redox regulated, being very sensitive to GSH and ROS. Nitrosothiols, in particular $S$-nitrosoglutathione, are a bioactive source of $\mathrm{NO}^{+}$prolonging the effective physiological half-life of $\mathrm{NO}^{\bullet}$ through controlled decay, and are important in trans-nitrosation reactions. This points to an important interplay between the cellular redox state, GSH/GSSG ratio, $S$-nitrosation and the formation of mixed disulfides, also implicated in cell signaling.

\section{Flavonoids: chemical and biological implications for their bioactivity}

\subsection{Flavonoids: antioxidant properties}

There has been considerable interest in recent years in the cytoprotective and neuroprotective effects of flavonoids, especially in the context of their modes of action as antioxidants. The electron-donating properties of flavonoids are well defined to explain their antioxidant properties in vitro [19,29,166,171,188]. Structurally important features defining the reduction potential of flavonoids are the hydroxylation pattern, a $3^{\prime}, 4^{\prime}$-dihydroxy catechol structure in the B-ring, the planarity of the molecule and the presence of 2,3-unsaturation in conjugation with a 4-oxo function in the C-ring. Many studies have described the antioxidant efficacy of flavonoids in inhibiting the lipid peroxidation $[29,82,171]$ and other biomolecules such as proteins and DNA [7,20,169] in vitro. Of particular importance to neurodegenerative diseases such as Parkinson's disease is the ability of flavonoids to inhibit peroxynitrite-mediated oxidation of dopamine and peroxynitrite-mediated nitration of tyrosine in vitro by a structure-dependent mechanism involving either the oxidation or nitration of the flavonoid ring system [98,150,151]. In addition, their ability to act as antioxidants in vitro is based on metal-chelating capacity [22,138] and on the quenching of singlet oxygen [203]. However, although flavonoids react rapidly with ROS/RNS in chemical systems in vitro, their reactions in vivo will be dependent on the form that is bioavailable to cells and tissues.

\subsection{Metabolism and distribution of flavonoids in mammals and the implication for their bioactivity}

Although the pool of data demonstrating the in vitro effects of flavonoids as antioxidants or modulators of protein functions is extensive, only little is known about the antioxidant potential and bioactivity of in vivo flavonoid metabolites. This is surprising since early investigations in the 1950-1960s in mammals already indicated that most of the flavonoids are conjugated and metabolized mainly in the liver or degraded by the colonic microflora (Fig. 3).

More recently, investigations of the sites and mechanisms of metabolism of flavonoids have established that flavonoids can be metabolised in the small intestine. Studies using the isolated rat small intestine have also established that flavonoids are substrates for $\beta$-glucosidases [184,192], UDP-glucuronyl transferases [110,111,192], and catechol- $O$-methyl transferases leading to methylation of $o$ dihydroxy catechol structures and that the major metabolites of epicatechin on transfer across the small intestine include $O$-methylated and glucuronidated forms [110] (Fig. 4). This is consistent with observations derived from human supplementation studies identifying $O$-methylated, glucuronidated and sulfated products in the circulation and eliminated in the urine. Metabolism can also occur in the colon and result in extensive modifications including hydrolysis, oxidation, and ring cleavage, forming secondary phenolic metabolites. Thus, the bioactivity of flavonoids in vivo is most likely to derive from their conjugates and metabolites and not necessarily from the ingested dietary forms.

In view of their powerful antioxidant properties in vitro [166], many studies have examined the absorption and bioavailability of the (epi)catechin flavanols, major constituents of read wine, tea, cocoa products, and other plantderived foods. Recent work by Okushio et al. [147] reported that both the $O$-methylated form and glucuronidated conjugates could be detected in rat urine after oral administration of epicatechin. Furthermore, epicatechin-5-O- $\beta$-glucuronide and catechin-5-O- $\beta$-glucuronide were detected in plasma, bile, and urine of rats after consumption of epicatechin and 


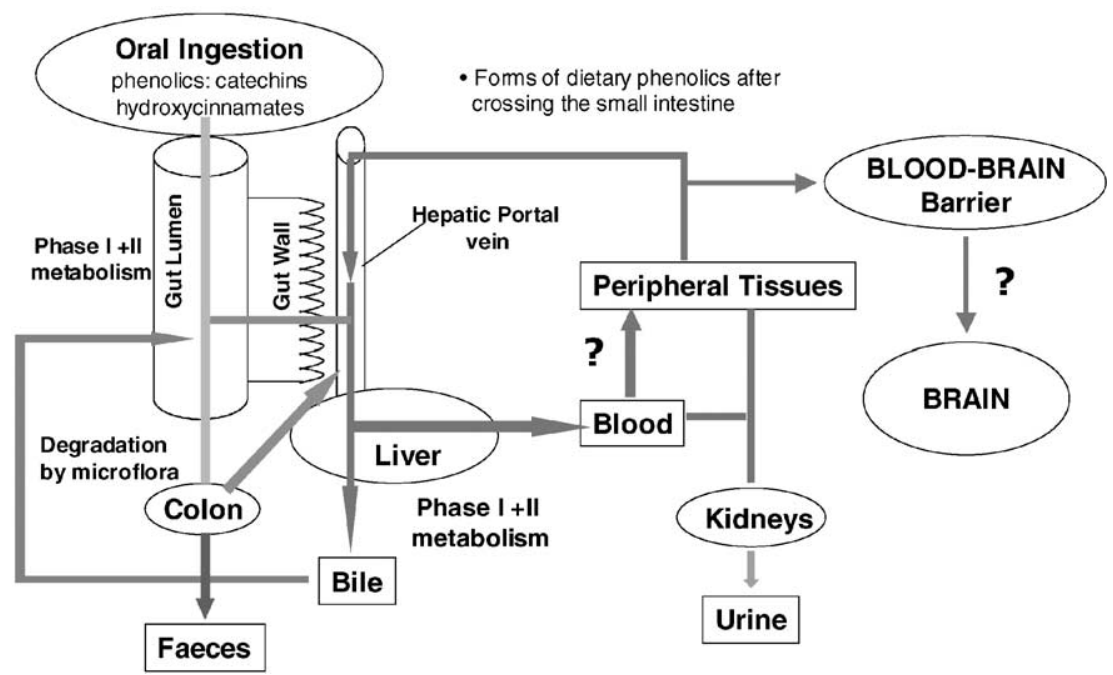

Fig. 3. Possible routes for dietary flavonoids after oral ingestion. Following oral ingestion flavonoids enter the gastrointestinal tract were they may be cleaved from their glycosidic moieties, taken up and undergo further Phase I/II metabolism. The remaining flavonoid aglycones and/or metabolised derivatives enter the portal vein and are transported to the liver were further metabolism will take place. Subsequently, flavonoid metabolites enter the circulation were they may be distributed to the peripheral tissues, perhaps even across the blood-brain barrier, or urinary excreted. Flavonoids, reaching the colon will be excreted or undergo extensive degradation by the colonic microflora. The resulting phenolic compounds may be absorbed.<smiles>COc1cc(O)cc(O)c1CC(O)[C@@H](OC)c1ccc(O)c(O)c1</smiles>

epicatechin-7- $\beta$-D-glucuronide<smiles>O=C(O)[C@H]1O[C@H](Oc2cc(O)c3c(c2)OC(c2ccc(O)c(O)c2)C(O)C3)[C@H](O)[C@H](O)[C@H]1O</smiles>

epicatechin-7-sulphate<smiles>O=S(=O)([O-])Oc1cc(O)c2c(c1)OC(c1ccc(O)c(O)c1)C(O)C2</smiles>

3'-0-methyl-epicatechin-7- $\beta$-D-glucuronide<smiles>COc1ccc(C2Oc3cc(OC4OC(=O)C5C(O)C(O)C(O4)C5O)cc(O)c3CC2O)cc1O</smiles>

3'-O-methyl-epicatechin<smiles>COc1cc(C2Oc3cc(O)cc(O)c3CC2O)ccc1O</smiles>

Fig. 4. Structures of potential in vivo metabolites of epicatechin. The major metabolites of epicatechin in vivo are glucuronidated and/or $O$-methylated and sulfated derivatives. Whereas the $O$-methylation of epicatechin always modifies the B-ring, glucuronidation might predominantly occur in five or seven position. 
catechin, respectively [78]. In humans, increases in $3^{\prime}-O$ methyl-catechin, sulphate, and glucuronide metabolites in plasma were observed after consumption of either red wine or de-alcoholised red wine [56].

There is currently considerable interest in the potential neuroprotective effects of (epi)catechin and its physiologically important metabolites. Thus, the question arises as to whether the in vivo metabolites of epicatechin, including $O$-methylated and glucuronidated derivatives, cross the blood-brain barrier, whether glucuronides have access to the brain due to their polarity or are hydrolyzed prior to uptake, or whether the $O$-methylated compounds are more likely to enter the brain due to their higher lipophilicity. Studies applying radio-labeled epigallocatechin gallate, a tea polyphenol, have demonstrated a wide distribution in mouse tissues, including the brain [198]. This was supported by other investigators describing the detection of the flavonoids hesperetin and naringenin, and naringenin glucuronide, in brain tissue following i.v. or oral administration $[155,206]$.

\subsection{Biological and cellular properties}

The major emphasis in recent years has concerned the potent in vitro antioxidant effects of flavonoids described in numerous publications (reviewed in [166]). However, flavonoids exhibit various effects on mammalian cells with interesting implications for inflammation [133], cardiovascular disease $[81,83]$ and cancer [58] involving the modulation of redox functions, calcium homeostasis [227], the activity of various enzyme systems, proliferation and differentiation, and the response to a variety of stimuli (reviewed in [134]). The effects of flavonoids are often pictured as beneficial for cell survival, preventive against oxidative insults and anti-carcinogenic. However, the actions of flavonoids are complex and often seemingly antagonistic or paradoxical. For example, while flavonoids are described as antioxidant agents protecting against oxidative insults to cells and apoptosis $[11,13,88]$, others have found flavonoids to be pro-oxidants and -apoptotic [33,212,221]. Thus, it becomes clear that the effects of flavonoids depend on different factors such as the specific compound used, the cell type, concentrations, experimental design, and the general context in which flavonoids are used. Furthermore, data reporting the action of flavonoids might often be observational, failing to explain the molecular/cellular basis of such observations. However, accumulating evidence suggests that flavonoids interact selectively within MAPK signaling cascades $[104,107]$. This could have important implications with regard to their possible sites of action in neurons since members of the MAPK family are involved in signaling to neuronal survival, regeneration and death $[48,136,228]$. Indeed, recent reports on oxidative stress in primary striatal neurons demonstrated that flavonoids, in particular epicatechin and kaempferol, are able to attenuate the activation of extracellular signal-related kinases (ERK1/2) and JNK and protect against neuronal cell death [178].

\section{MAP kinase signaling}

MAP kinase signaling (MAPK) pathways transduce extracellular and intracellular stimuli into cellular responses. In general, MAPK signaling motifs are highly conserved throughout evolution and appear to be essential signal transduction systems in yeast, higher eukaryotes as well as in plants. These responses consist of phosphorylation of cytosolic or nuclear target proteins and activation of transcription factors, which consequently modulate gene expression. Mammals express at least three distinctly regulated groups of MAPKs, which may exist in different isoforms: ERK1/2, c-Jun amino-terminal kinases (JNK1/2/3), and p38 kinases $(\mathrm{p} 38 \alpha / \beta / \gamma / \delta)$ (reviewed in [34]).

Each MAPKK can be activated by more than one MAP$\mathrm{KKK}$, increasing the complexity and diversity of MAPK signaling. To be activated, all members of the MAPK family require dual phosphorylation of a threonine and tyrosine residue within the catalytic domain by their respective upstream kinase. Hence ERK, JNK, and p38 contain the specific dual phosphorylation motif Thr-Glu-Tyr, Thr-Pro-Tyr, and Thr-Gly-Tyr, respectively. Besides the upstream kinases, the activation of MAPKs critically depends on the activity of a special family of dual specificity phosphatases the MAP kinase phosphatases (MKPs) that inactivate MAPK and, therefore, play an important role in the dynamics of MAPK signaling [34].

Active MAPKs function as modulators for differentiation, proliferation, cell death, and survival. Commonly, the activation of ERK1/2 has been linked to cell survival, whereas that of JNK and p38 (also called the stress-activated protein kinase (SAPK)) has been associated with apoptosis. This perspective is an oversimplification and the actual roles are highly dependent on the cell type, the state of cell development, the kind of stimulus and the context of stimulation.

Activation of ERK1/2 can lead to the phosphorylation of a wide array of potential targets in cytosol or nucleus. For example active ERK1/2 can activate transcription factors [215] and phosphorylate specific effector kinases-the MAPK-activated protein kinases (MAPKAPKs) such as the mitogen- and stress-activated kinase-1 (MSK1) or the pp90 ribosomal S6 kinase (RSK) [197]. RSK phosphorylates the Bcl-2 family member Bad, thereby inhibiting its pro-apoptotic activity [18]. RSK and MSK1 are also potent activators of the cAMP response element binding protein (CREB), a transcription factor for Bcl-2 and, therefore, an important factor for cell survival [51]. This would suggest that active ERK1/2 plays an important role in pro-survival signal transduction processes. Indeed different studies clearly indicate that under certain conditions the activation of ERK1/2 is essential to neuronal survival [18,218]. Furthermore, the activation of Ras, an initiator of the ERK1/2 signaling cascade, has been shown to also activate the phosphoinositol 3-kinase (PI3-kinase)/AKT pathway, another important survival pathway in neurons, demonstrating possible interlinks between different survival signals [129]. 
Interestingly, the protective effects initiated by Ras activation involve the suppression of pro-apoptotic signals such as the tumor suppressor protein p53 and the Bcl-2 family member Bax and are less potent if either the ERK1/2 or the PI3-kinase/AKT pathway is selectively inhibited [129]. Thus, this describes the outcome of a signal transduction process as the sum of different actions towards the same target and underlines the importance of interlinks between signaling cascades in promoting and enhancing specific signals.

However, the actual role of ERK1/2 seems to be dependent on various parameters, since inhibition of ERK1/2 activation during focal ischemia [3], oxidative stress [198], and a model for hippocampal seizures [140] attenuated neuronal death and cellular injury, indicating a pro-death singling role for ERK1/2. In addition, the inhibition of ERK1/2 activation has been demonstrated to protect a mouse neuronal cell line and rat primary cortical neurons from oxidative stress-induced neurotoxicity [175]. Furthermore, nitrosative stress-induced apoptosis in a hippocampal model of glutamate-mediated neurotoxicity has been shown to involve activation of ERK1/2 [228].

Active JNKs have a wide range of potential phosphorylation targets in the nucleus as well as in the cytoplasm. Nuclear substrates for JNKs are transcription factors such as c-Jun [1,75,92], ATF-2 [92], and ELK-1 [30]. As far as is known JNKs are the only kinases capable of phosphorylating c-Jun in vivo. c-Jun is part of the activator protein-1 (AP-1) transcription factor, which either exists as Jun homodimer or as a Jun/Fos heterodimer [95]. The transcriptional activity of the AP-1 complex is increased [95] upon phosphorylation of Ser-63 and -73 of c-Jun by JNK [160]. In addition to c-Jun, JNKs also phosphorylate other AP1 proteins, including JunB and JunD $[25,95]$. The regulatory effect of JNKs on AP-1 transcription might not only be due to phosphorylation of Jun but may also involve JNKregulated ubiquitin-mediated degradation of AP-1 proteins $[66,67]$. JNKs appear to be essential in cytokine and stressinduced activation of AP-1 but are not required for AP-1 activation in response to other stimuli. Cytosolic substrates for JNKs include cytoskeletal proteins, the tumor suppressor protein p53 [24,65], the mitogen-activated kinase activating death domain protein (MADD) [232], glucocorticoid receptors [167], $\mathrm{Bcl}-2$, and $\mathrm{BclX}_{\mathrm{L}}$ [220], neurofilaments, tau $[84,165]$ and STAT-3 a member of the signal transducer and activators of transcription (STAT) family [122,207].

Although JNK activation is often associated with cellular injury and degeneration it also plays an important part in embryonic morphogenesis, memory formation, and immune defence. The pro-apoptotic action of JNKs in neurons was initially investigated in neuronal cell death following the withdrawal of neurotrophic factors [218]. It was found that JNK activation contributed to the apoptotic response and that JNK-mediated apoptosis was suppressed by activation of survival pathways. Studies in mice utilizing the disruption of the neuronal gene JNK3 confirmed the role of
JNK in stress-induced neuronal apoptosis by demonstrating that JNK3-knockout mice were developmentally normal but resistant to excitotoxin-induced neuronal apoptosis [222]. These findings were supported by observations in mice with a mutation in the c-Jun gene that altered the JNK phosphorylation sites of c-Jun and led to a resistance against kainic acid triggered death of hippocampal neurons [15]. Further support arose from data obtained using dominant-negative c-Jun mutants, which reduced sympathetic neuronal death following NGF withdrawal [214]. A pro-apoptotic function has also been suggested for JNK activation in NGFwithdrawal-induced neuronal death [59] in a hippocampal model of Huntington's disease [124] and in beta-amyloidinduced neuronal apoptosis [204]. However, the apoptotic process does not occur in JNK-knockout mice [222] or mice expressing a mutant form of c-Jun lacking the JNK phosphorylation site [15]. In addition, the indirect inhibition of JNK by CEP-1347 protected neuronal PC12 cells and sympathetic neurons in vitro from death following trophic factor withdrawal, beta-amyloid exposure, UV-radiation and oxidative stress [126,205]. Furthermore, CEP-1347 protected nigral neurons in vivo against $\mathrm{MPP}^{+}$-induced neuronal death [173] implicating again the involvement of JNK in neurodegeneration. Moreover, JNK activity and apoptosis in cerebellar granule neurons was enhanced following inhibition of the pro-survival pathway PI3-kinase/AKT [185]. Finally JNKs seem to be indirectly involved in other apoptotic pathways by enhancing transcription of death receptors such as Fas-L [62] or by activating and stabilizing the p53 protein [24]. Together these data strongly support JNK involvement in apoptosis signaling in neurons.

A recent review by Davis [48] on the role of JNK in apoptosis suggested a mechanism of JNK-dependent apoptosis involving the mitochondria and caspase-3. This hypothesis is based on observations in primary murine embryonic fibroblasts (MEF) lacking the genes for $J N K 1$ and $J N K 2$ (JNK null; no JNK1/2 protein/activity). These JNK null MEF exhibit profound defects in stress-induced (UV-radiation, DNA-alkylation, translational inhibition) apoptosis [204]. The defect in the execution of apoptotic cell death was caused by the failure to initiate JNK-induced cytochrome $c$ release from the mitochondria [204]. This malfunction is significant since it is critical for the subsequent sequential activation of Apaf-1 [120], the initiator-caspase caspase-9 [76] and finally the effector-caspase caspase-3 [217] all of which are essential in the execution of apoptosis. Tournier et al. [204] suggested that the apoptotic response is suppressed in JNK null MEF due to the absence of JNK, which is needed to initiate the apoptotic cascade (Fig. 5). However, it is not clear yet by which molecular mechanism JNK mediates the release of cytochrome $c$ from the mitochondria. Although a c-Jun-activated transcription seems possible (Fig. 5) [15,214], it is not required for UV-induced apoptosis [204]. Several studies point to the JNK mediated in vitro phosphorylation/inactivation of the mitochondria-associated anti-apoptotic proteins $\mathrm{Bcl}-2$ and $\mathrm{BclX}_{\mathrm{L}}[40,61,94]$ as a 


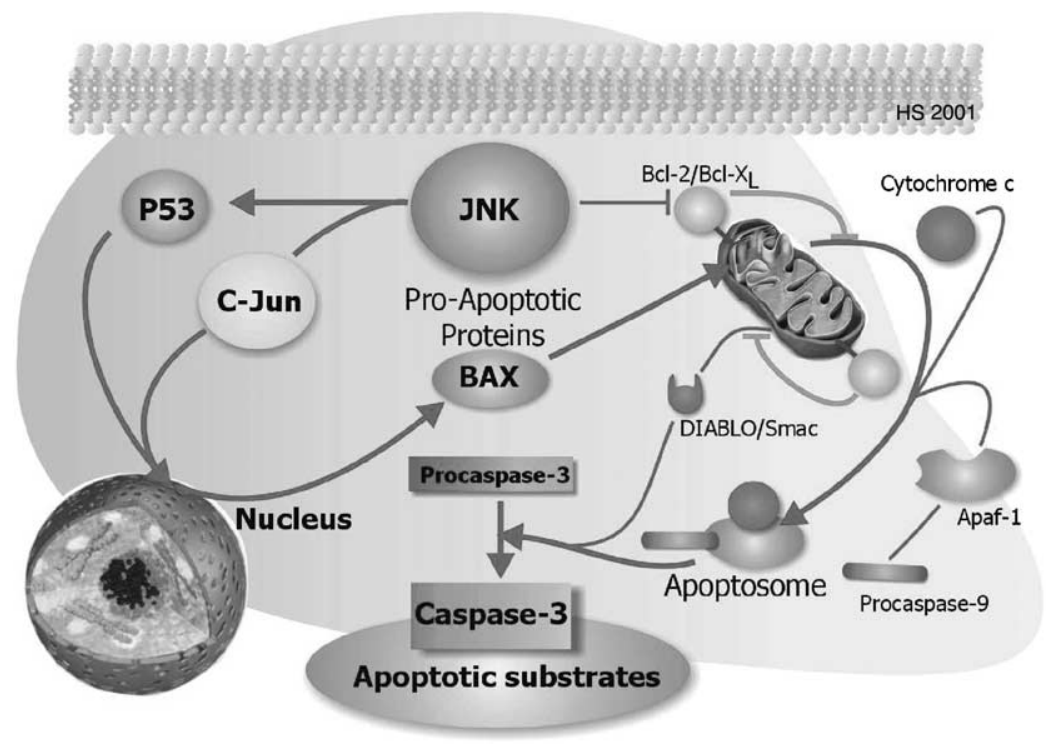

Fig. 5. The possible involvement of JNK signaling in the execution of cell death. Once activated JNK can phosphorylate p53, which in term stabilizes and activates this apoptotic mediator resulting in the suppression of the anti-apoptotic protein Bcl-2 and the induction of the pro-apoptotic protein Bax. Active JNK may also influence the expression of other pro-apoptotic molecules via the c-Jun/AP-1-mediated regulation of their expression. The proposed function for active JNK as mediator of the phosphorylation of the mitochondria-associated proteins Bcl-2 and BclX $\mathrm{L}_{\mathrm{L}}$ will alter their anti-apoptotic functions and may subsequently result in the release of cytochrome $c$ or other apoptotic factors such as DIABLO/smac from the mitochondria. The release of cytochrome $c$ will in turn promote the formation of the apoptosome, subsequently leading to the activation of caspase- 3 one of the major executors of apoptosis.

possible mechanism, since $\mathrm{Bcl}-2 / \mathrm{BclX} \mathrm{X}_{\mathrm{L}}$ are known to regulate cytochrome $c$ release (Fig. 5). Others proposed an as yet unknown adaptor protein as the mediator for JNK actions. Further studies are needed to substantiate this hypothesis and establish the molecular mechanisms.

In summary, it is becoming increasingly clear that JNK activation is involved in apoptotic processes in vivo and in vitro either by direct effects of JNK mediated c-Jun phosphorylation, the adverse effects on survival pathways or the indirect effects on cell function via other mediator systems. But apoptosis is not the inevitable outcome of JNK signaling. In fact, the overall cellular outcome of a signal transduction process might rather be determined by the sum of both pro-survival and -apoptotic signaling pathways.

\subsection{MAPK signaling under oxidative stress}

Oxidative stress seems to be a major stimulus for MAPK signaling cascades with cell survival or death as a possible consequence. The observation that multiple pathways are sensitive to alteration in intracellular ROS/RNS concentrations indicates that this might represent a common cellular pathway to signal a large diversity of different stressful stimuli. Accordingly a large number of redox-responsive transcription factors and genes have been identified [5].

Oxidative stress has been shown to contribute to the neuropathology of a number of neurodegenerative disorders [77], including Alzheimer's disease [14], Parkinson's disease [231] and Huntington's disease [4], as well as being implicated in neuronal loss associated with age-related cognitive decline $[64,161]$, cerebral ischemia/reperfusion injuries, seizures $[44,148]$, trauma, and neuroinflammation [130,131].

High levels of ROS and RNS can disrupt the normal redox state and shift cells into the state of oxidative stress, hallmarked by intracellular increases in products of lipid peroxidation, hydrogen peroxide, and elevated damage to other biomolecules. It is often stated that the damage to important biomolecules such as proteins and DNA as a result of oxidative stress leads to cell injury or death. Importantly, this oversimplification ignores a number of stress response mechanisms that cells have developed to coordinate reactions that ultimately determine the outcome following an oxidative insult. Among the main stress signaling pathways or central mediators in stress response to oxidative insults are the MAPK cascades, the PI3-kinase/AKT, the nuclear factor $\kappa \mathrm{B}(\mathrm{NF}-\kappa \mathrm{B})$ signaling system, p53 activation and the heat shock protein response. In summary, accumulating evidence seemingly indicates a central role for the MAPK signaling cascade in neuronal survival and death during the development and the aging of the CNS, as well as in the pathology of neurodegenerative diseases $[48,136,226]$.

Oxidative stress seems to be a major stimulus for MAPK signaling cascades. However, this picture would appear to be too simplistic since a shift of the overall reductive environment that most cells maintain under physiological conditions towards reduction also leads to the activation of MAPK signal transduction with cell survival or death as a possible consequence. 
Growth factor receptors have been shown to undergo enhanced phosphorylation in response to oxidative insults like hydrogen peroxide or UV-radiation initiating ERK1/2 activation $[115,116,210]$. This is consistent with demonstrations of the mitogenic effects of low concentrations of hydrogen peroxide [23]. However, the inhibition of ERK1/2 activation has been shown to protect a mouse neuronal cell line and rat primary cortical neurons form oxidative stress-induced neurotoxicity [1] demonstrating a possible involvement in cell death. The JNK signaling cascade has been reported to be activated by a wide range of different oxidants/reductants including hydrogen peroxide $[135,218]$, lipid peroxidation products [6,191], different types of radiation [63], modulators of intracellular glutathione status [145], peroxynitrite [71], glutamate [180], dithiothreitol, and nitric oxide [152]. Although the links between redox status and MAPK signaling have been known for some time, data demonstrating the molecular basis of such links and identifying the sensors in this redox response are few.

Accumulating evidence indicates that members of the MAPK family or their upstream or downstream partners have such redox-sensitive motifs. For example, JNK itself exhibits a redox-sensitive cysteine residue that is not present on ERK or p38 [153]. An additional mechanism in JNK redox regulation is its binding to redox-sensitive proteins such as glutathione $S$-transferase (GSHST) [2]. It has been shown that under non-stressed conditions, JNK is associated with GSHST resulting in the inhibition of JNK activity, but that GSHST dissociates from JNK following UV-radiation or hydrogen peroxide treatment $[2,224,225]$. Forced expression of GSHST decreased JNK activity, increased c-Jun ubiquitination and reduced c-Jun-mediated transcription [2]. In addition, GSHST expression in NIH 3T3 cells lead to the attenuation of hydrogen peroxide-induced JNK activation as well to an increase in ERK1/2 activity [224,225]. Similarly GSHST and the redox regulatory protein thioredoxin (Trx) bind under non-stressed conditions to the apoptosis signalregulating kinase-1 (ASK1) [39,170,225], an upstream activator of JNK, and inhibit JNK activity. However, oxidative insults cause the dissociation of the Trx-ASK1 and GSHST complex and the subsequent activation of JNK $[39,170,225]$.

$\mathrm{Ca}^{2+}$-Homeostasis is another important mediator/regulator of oxidative stress-induced signaling, since both ERK and JNK are sensitive to changes in intracellular $\mathrm{Ca}^{2+}$. concentrations $[60,102,142]$. This $\mathrm{Ca}^{2+}$-sensitivity of ERK/JNK signaling might play a role in oxidative stressinduced signaling events, since it has been demonstrated that oxidative insults often influence normal $\mathrm{Ca}^{2+}$ homeostasis in cells. With regard to ERK1/2, Samanta et al. [172], demonstrated for the first time that hydrogen peroxide induced activation of ERK1/2 in primary neurons is strictly dependent on extracellular calcium. $\mathrm{Ca}^{2+}$-dependent MAPK signaling has also been suggested to play a role in glutamate receptor-mediated neuronal stress [156]. The influx of $\mathrm{Ca}^{2+}$ into the cytosol from the extracellular space or from intracellular stores following a stressful stimulus can activate the $\mathrm{Ca}^{2+} /$ calmodulin kinases, which in turn can stimulate the activation of all three MAPKs [142]. The effect of ROS/RNS on MAPK activation is complex and occurs at multiple levels and further results are needed to elucidate the molecular basis of these interactions.

\section{Nitric oxide and MAPK signaling}

The role of $\mathrm{NO}^{\bullet}$ in cellular signaling was first identified in the vascular system with respect to the regulation of smooth muscle contraction, important for vascular tone [85]. $\mathrm{NO}^{\bullet}$ is a potent activator of soluble guanylate cyclase through binding to the essential heme $\mathrm{Fe}^{2+}$ [85]. This leads to elevated cGMP levels and increased activity of cGMPdependent kinases and phosphatases. $\mathrm{NO}^{\bullet}$ has been identified as a novel neural messenger, promoting $\mathrm{Ca}^{2+}$-dependent neurotransmitter release from synaptic storage vesicle [70]. $\mathrm{NO}^{\bullet}$ modulates exocytosis through cGMP-dependent protein phosphorylation cascades following the classic activation of soluble guanylate cyclase [70]. The high diffusibility of $\mathrm{NO}^{\bullet}$ makes it an ideal retrograde signal for the two forms of synaptic modulation required for learning and memory, namely long-term potentiation in the hippocampus and longterm depression in the cerebellum [70].

Besides a role in differentiation and synaptic plasticity, $\mathrm{NO}^{\bullet}$ has also been implicated in neuronal apoptosis, and consequently, in neurodegenerative diseases, specifically when $\mathrm{NO}^{\bullet}$ production is increased to toxic levels $[49,64,77,123,202]$. In particular, $\mathrm{NO}^{\bullet}$ has been linked to the phenomenon of excitotoxicity involving the over-stimulation of the NMDA receptor by glutamate, subsequently triggering a strong intracellular accumulation of $\mathrm{Ca}^{2+}[141]$. This $\mathrm{Ca}^{2+}$ overload in neurons leads to a substantial increase in the activity of $\mathrm{Ca}^{2+} /$ calmodulin-dependent nitric oxide synthase (neuronal NOS) resulting in a high intracellular concentration of $\mathrm{NO}^{\bullet}$, which has been identified as a mediator of glutamate-induced neuronal death [49]. Furthermore, microglia activation during neuroinflammation is associated with induction of inducible nitric oxide synthase (iNOS) expression leading to a large and sustained $\mathrm{NO}^{\bullet}$ production, which also appears to be causally linked to neuronal apoptosis and neurodegeneration [100,121].

On the contrary, there is growing evidence for cGMPindependent $\mathrm{NO}^{\bullet}$-mediated cell signaling towards neuronal survival. Depending on its intracellular concentration and the overall cellular context, $\mathrm{NO}^{\bullet}$ has been implicated in mechanisms protecting against stress-induced cell injury. The GTP-binding protein Ras is an intermediate in the transduction of signals from membrane receptor tyrosine kinases to the stimulation of MAP kinases [176] (Fig. 6). Ras appears to be a common signaling target of reactive free radicals, including $\mathrm{NO}^{\bullet}$, and agents that modulate the cellular redox status, such as $\mathrm{H}_{2} \mathrm{O}_{2}$ and $\mathrm{GSH}$ [115]. $\mathrm{NO}^{\bullet}$ activates Ras by $S$-nitrosation of a highly conserved cysteine residue, leading to GDP/GTP exchange and downstream signaling [114]. 


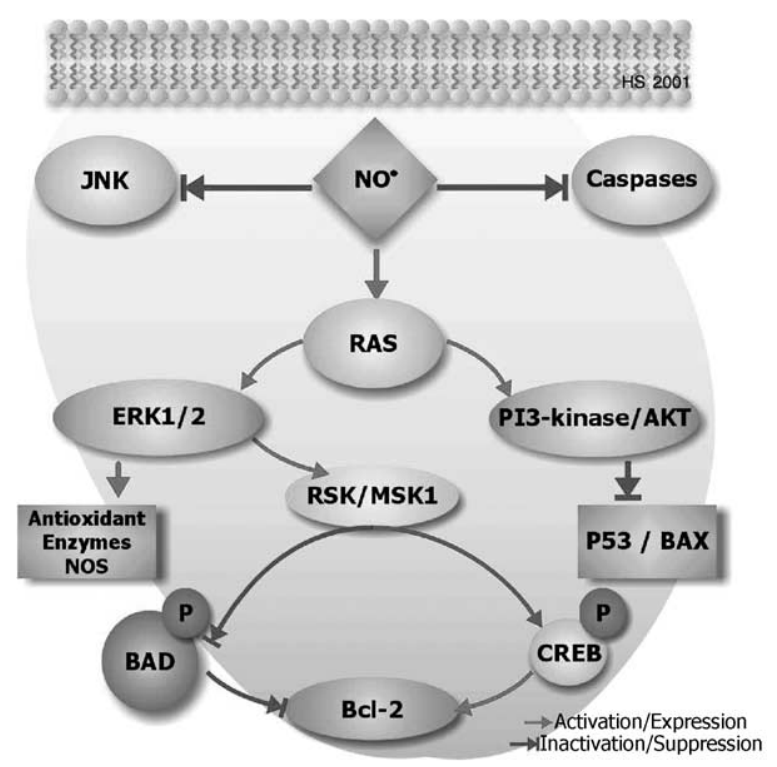

Fig. 6. Potential anti-apoptotic mechanisms mediated by nitric oxide. The nitrosation of Ras mediated by nitric oxide potentially leads to the activation of ERK1/2 or the PI3-kinase/AKT pathway resulting in the suppression of pro-apoptotic proteins such as p53 and Bax or in the upregulation of antioxidant enzymes. Furthermore, Ras activation might mediate the phosphorylation/activation of the CREB, a transcription factor for Bcl-2 and the phosphorylation/inactivation of the pro-apoptotic protein $\mathrm{Bad}$. In addition, the $\mathrm{NO}^{\bullet}$-mediated nitrosation of JNK and caspases may also contribute to the anti-apoptotic properties of $\mathrm{NO}^{\bullet}$.

Thus, it has been proposed that this cysteine reside may represent an important molecular redox trigger, whereby cells can respond to the ambient redox status. Indeed, through Ras activation, $\mathrm{NO}^{\bullet}$-related species can modulate the activity of all three MAPKs [114,115,152]. For example, activation of ERK1/2, as discussed earlier, may lead to the phosphorylation/inactivation of the pro-apoptotic protein Bad, the expression of anti-apoptotic proteins such as Bcl-2 and the suppression of pro-apoptotic proteins such as Bax (see above) (Fig. 6). In contrast, however, NO• can directly suppress JNK activation via $S$-nitrosation of a redox-sensitive residue that is not present on ERK or p38 [152,190], thereby supporting pro-survival mechanisms (Fig. 6). Alternatively, c-Jun, the substrate for JNK, can be directly $S$-nitrosated by $\mathrm{NO}^{\bullet}$ [103]. In addition, signaling by kinase-catalyzed phosphorylation can be counteracted by phosphatase-catalyzed de-phosphorlyation, both systems representing targets for $\mathrm{NO}^{\bullet}$. For example, the protective effect of $\mathrm{NO}^{\bullet}$ against tumor necrosis factor- $\alpha$-induced apoptosis in endothelial cells involves prolonged activation of ERK1/2 following inhibition of MAPK phosphatase-3 by $\mathrm{NO}^{\bullet}$ [103].

Ultimately, $S$-nitrosation can thus, regulate several redoxsensitive transcription factors including NF-кB, AP-1, Sp1 , and p53, and increase levels of active c-Fos and c-Jun [127]. Indeed, the expression of some enzymes implicated in antioxidant defences such as the enzymes for glutathione synthesis [235] and heme oxygenase [37] exhibit ERK1/2 dependency in the regulation of their expression (Fig. 6). Furthermore, the transcription of $\mathrm{Cu} / \mathrm{ZnSOD}$ is regulated by the transcription factor ELK-1 [35] and the promoter for MnSOD expression contain binding sites for Sp1, AP-1, and CREB [47,181], all of which have been linked to regulation by ERK1/2 [18,182] (Fig. 6).

In turn, MAPK are also involved in the regulation of the gene expression of all three NOS isoenzymes. The expression of iNOS (NOS-2) is regulated by all three MAP kinase pathways in a variety of cell types [16,32,46,93,108,189]. For example, JNK and ERK1/2 pathways are necessary for lipopolysaccharide (LPS)- and interferon- $\gamma$-stimulated iNOS expression in mouse macrophage cells, possibly via $\alpha$-tumor necrosis factor secretion, whereas p38 inhibited induction [31]. The induction of endothelial NOS (eNOS, NOS-3) by estrogen, fibroblast growth factor or epidermal growth factor in endothelial cells involves the Ras-ERK pathway $[38,233]$. eNOS is phosphorylated, and thus activated, by the serine/threonine protein kinase AKT, which is recruited to the cell membrane by PI3-kinase as an antiapoptotic mechanism in the response of endothelial cells to shear stress [54]. In the case of neuronal NOS (nNOS, NOS1), the induction of mRNA, protein expression and activity by nerve growth factor (NGF) in PC12 cells involves activation of the Ras-ERK1/2 pathway, initiating a kinase cascade proceeding from Raf via MEK to ERK [177].

In this regard, it is very interesting that several studies have shown that specific flavonoids can suppress the induction of iNOS gene and protein expression, and $\mathrm{NO}^{\bullet}$ production by cytokines and endotoxins in mouse macrophage RAW 264.7 cells $[99,109,152]$. The mechanism did not include a direct inhibitory effect on enzyme activity, but rather the modulation of cell signaling pathways necessary for NOS gene expression. This has potentially important implications for the role of microglial iNOS gene expression and neuroinflammation in neurodegenerative diseases. Taken together, it becomes increasingly clear that a potential feedback loop exists between NOS, NO ${ }^{\bullet}$ and MAPK - all of which may be modulated by flavonoids-promoting cross-talk between signaling pathways and thus, influencing a variety of different cellular function, especially with regard to cell survival and cell death.

\section{Apoptosis, mitochondrial function and MAPK signal transduction}

There is a growing recognition that neuronal cell death characteristic of neurodegeneration is primarily a result of apoptosis rather than necrosis [202,228]. The molecular mechanisms underlying oxidative stress-induced neuronal damage are emerging and appear to involve an apoptotic mode of death in which ERK1/2 [175,196] and JNK $[48,136,226]$ have been strongly implicated. Furthermore, there is strong evidence for involvement of mitochondrial 
defects in neurodegenerative diseases, with neuronal cell death arising directly from mitochondrially generated ROS, ATP depletion or activation of the mitochondrialdependent apoptotic pathways $[48,202,226]$. Apoptosis, or programmed cell death, is an active, controlled process involving multiple signaling cascades, expression of genes and the modulations of mitochondrial functions. The precise mechanism of apoptosis is complex and depends on the proapoptotic stimuli, cell type, redox status of the cell and the overall context of cellular functions and should be seen as the sum of pro-apoptotic and anti-apoptotic signals. Initially apoptosis was believed to occur independently of mitochondrial factors. Now it is recognized that mitochondria play a central role in oxidative stress-induced apoptosis [74] since they contain cytochrome $c$ and other pro-apoptotic factors essential in Fas receptor-independent apoptosis [120,204]. The emerging view is that pro-apoptotic stimuli result in a transient collapse of the mitochondrial transmembrane potential, which is temporally correlated with opening of the permeability transition pore and the release of apoptosisinitiating factors (AIF) such as cytochrome $c$ and DIA$\mathrm{BLO} / \mathrm{smac}$ into the cytosol, subsequently committing the cell to die by mechanisms, involving the Apaf-1-mediated activation of the executing caspase caspase- $3[74,80,202]$. Thus, blocking the release of AIF might be the key to prevent oxidative stress-induced apoptosis. However, other investigators reported apoptotic processes involving the depolarization of the mitochondria without translocation of cytochrome $c$ to the cytosol [74,101]. This indicates additional mechanisms leading to the recruitment of apoptosisexecuting caspases and cell type specific differences in the mechanism of apoptosis. Taken together, blocking mitochondrial permeability transition (mPT) might be a more general feature than cytochrome $c$ release in preventing apoptotic processes. Indeed, the anti-apoptotic protein Bcl2 is believed to protect against apoptosis by preventing $\mathrm{mPT}$ and the opening of the mPT pore (mPTP). Bcl-2 is concentrated in the mitochondrial outer membrane, where its interactions with other members of the $\mathrm{Bcl}-2$ family $\left(\mathrm{Bax}, \mathrm{Bad}, \mathrm{BclX}_{\mathrm{L}}\right.$ ) or with proteins of the $\mathrm{mPTP}$ are believed to be essential for the anti-apoptotic effects of Bcl-2 $[40,61,80]$.

In the context of oxidative stress-induced apoptosis, caspase inhibitors have been shown to block 4-HNE-induced activation of JNK [27] and reduce oxidative stress-mediated neuronal death $[96,178]$. Interestingly, in endothelial cells oxLDL-induced apoptosis correlated with the downregulation of the cellular caspase inhibitor FLIP (FLICE-inhibiting protein; FLICE: Fas-associated death domain homologues ICE-like protease) without impacting on the expression of members of the Bcl-2 family ( $\mathrm{BclX} \mathrm{L}_{\mathrm{L}}, \mathrm{Bcl}-2$, Bax) [174]. In addition, antioxidants and thiol reductants and, under some conditions ROS, can block or delay apoptosis. This places the cellular redox state as an important determinant in apoptotic signal transduction. In fact, the burst of mitochondrial $\mathrm{O}_{2}{ }^{-}$generation associated with apoptosis has been linked to cytochrome $c$ release from mitochondria, and can be prevented by $\mathrm{Bcl}-2$ over-expression [26]. The vectorial release of mitochondrial $\mathrm{O}_{2}{ }^{-}$(more correctly, $\mathrm{H}_{2} \mathrm{O}_{2}$ ) to the cytosol may, in turn, be important in cell signaling [143], e.g. activation of MAPK such as JNK [135,218]. Indeed, a wealth of data on apoptosis is accumulating and emphasizing the potential role of the MAPK signaling cascade and mitochondrial function. The MAPK signal transduction could be regarded as a potential cross-link between the different apoptotic pathways. For example, JNK has been proposed to modulate the release of pro-apoptotic factors from the mitochondrion (Fig. 5) and stabilizes the pro-apoptotic p53, which in term may impairs mitochondrial functions thorough the expression of p53AIP1 and a subsequent permeability transition [144]. On the contrary p53 might activate JNK via the MEKK4 involving the p53-mediated expression of the growth arrest and DNA damage-induced protein (GADD45) [201]. Furthermore, the JNK mediated mitochondrial dysfunction can lead to caspase-3 activation (Fig. 5) but on the other hand caspases may activate JNK via MEKK1 [183].

Brookes et al. [21] observed that $\mathrm{NO}^{\bullet}$ modulated cytochrome $c$ release from mitochondria in a concentrationdependent manner. At low concentrations, $\mathrm{NO}^{\bullet}$ prevented $\mathrm{Ca}^{2+}$-induced cytochrome $c$ release, involving the dissipation of the electrochemical gradient, with a concomitant prevention of intramitochondrial $\mathrm{Ca}^{2+}$ accumulation and a closing of the PTP. The primary event involved an inhibition of $\mathrm{O}_{2}$ consumption, consistent with the fact that $\mathrm{NO}^{\bullet}$ can reversibly inhibit cytochrome $c$ oxidase [41]. However, at high concentrations $\mathrm{NO}^{\bullet}$-induced cytochrome $c$ release, most likely through peroxynitrite formation [21].

Besides preventing cytochrome $c$-dependent activation of caspase- 3 , $\mathrm{NO}^{\bullet}$ may also upregulate anti-apoptotic proteins, such as heat shock protein-70 and Bcl-2 via Ras activation (Fig. 6). In addition, the activation of Ras by NO${ }^{\bullet}$ as discussed earlier has important anti-apoptotic implications involving either the RSK/MSK1-mediated inhibition of Bad and expression of $\mathrm{Bcl}-2$ as well as the suppression of p53 and Bax (Fig. 6). Furthermore, $S$-nitrosation modulates the activity of other proteins involved in cell death/survival processes such as caspases. Li et al. [120] demonstrated that $\mathrm{NO}^{\bullet}$ can inhibit seven members of the caspase family directly via $S$ nitrosation. The latter include caspase- $1,-2,-3,-4,-6,-7$, and -8 , i.e. representatives from each of the tentative three subfamilies of caspases. On the contrary, it should be noted that through inhibition of $\mathrm{O}_{2}$ consumption, $\mathrm{NO}^{\bullet}$ can modify electron flux through discrete sections of the respiratory chain. This leads to enhanced mitochondrial $\mathrm{O}_{2}{ }^{-}$generation, mainly due to auto-oxidation of ubiquinol [157-159]. Thus, it can be argued that the mitochondria can transduce a nitrosative signal into an oxidative signal, consistent with the proposed role of mitochondrial ROS in cytosolic signaling pathways [143].

However, it remains to be clearly established what intracellular concentrations of $\mathrm{NO}^{\bullet}$ are required for the intracellular nitrosation of proteins and whether or not these 
concentrations are relevant under physiological/pathological conditions.

\section{Flavonoids: neuroprotective agents in vivo and in vitro?}

Data on the anti-apoptotic effects of flavonoids in the context of the CNS or CNS-derived cells are starting to accumulate but not as extensively as for other cells or tissues. Recent epidemiological and dietary intervention studies in humans and animals suggest that flavonoids may play a useful role in preventing neurodegeneration, especially age-related cognitive, motoric, and mood decline and protect against oxidative stress as well as cerebral ischemia/ reperfusion injuries. Studies in humans using flavonoidcontaining plant extracts, such as Ginkgo biloba, or pure flavonoid preparations demonstrate positive effects on cognitive function and memory performance in healthy volunteers from all age groups $[42,97,213]$ as well as in patients with age- or Alzheimer' disease-associated dementia [128,146,208]. Watanabe et al. [211] reported that G. biloba supplementation in mice had neuromodulatory effects as indicated by a more than three-fold increase of mRNA expression for neuronal tyrosine/threonine phosphatases1 , microtubule-associated tau, prolactin, different calcium, and chloride channels as well as transthyretin. Flavonoidassociated antioxidant interventions have also been proposed to be beneficial in hypoxia/ischemia, seizures, Parkinson's disease, increased survival in brain cancers, and general age-related neurodegeneration $[50,73,89,125]$. However, since the flavonoids used in these studies were given as food extracts or preparations containing other potential bioactive or antioxidant components rather than as a pure flavonoid fraction, the results may not reflect solely the effects of flavonoids. Furthermore, the mechanisms of flavonoid actions remain speculative and may involve the antioxidant properties, the modulation of receptors and calcium homeostasis or a combination thereof [89].

In vivo studies in animals demonstrate protective effects of the flavonoids epicatechin and quercetin against ischemia/reperfusion-induced neuronal injury [86,187]. Furthermore, flavonoids showed protective effects against an increase in brain lipid peroxidation following Vitamin E deprivation [219], attenuated neuronal damage induced by ethanol administration $[113,199]$ and reduced $O$-ethyl-S,Sdipropyl phosphorodithioate-induced neurotoxicity in mice [163]. Interestingly, the oral administration of a catechincontaining antioxidant preparation significantly increased the life span of senescence-accelerated mice [112] and increased SOD activity in the mitochondrial fraction of the striatum and the midbrain, decreased products of lipid peroxidation in cortex and cerebellum, and attenuated the iron(II) chloride-induced formation of markers of DNA damage in the cortex of aged rats [106]. The authors of this study relate the observed effects mainly to the rather unspe- cific antioxidant activity of catechin and other compounds contained in the preparation and fail to give further insights in the mechanisms related to the increase in mitochondrial SOD activity. Other investigators reported an attenuation of age-related decline in cognitive function and loss of behavioral deficits following long-term dietary supplementation with anthocyanidin-rich foods or plant extracts $[90,91,216]$. The investigators used several neuronal and behavioral parameters including dopamine-release, GTP-activity, calcium buffering in striatal synaptosomes, rod walking tasks and the water maze performance to elucidate possible mechanisms involved $[90,91]$.

In vitro, observations in neuronal PC12 cells demonstrated the protective effects of $G$. biloba extract against hydrogen peroxide-mediated [209] or beta-amyloid-induced neuronal death $[186,223]$. Other authors reported beneficial effects of G. biloba extract against beta-amyloid-mediated neurotoxicity in primary hippocampal neurons $[11,57]$ and implicated antioxidant activities and the modulation of intracellular calcium levels in PC12 cells [209] as possible mechanisms of action. Other lines of research focused on the binding of flavonoids such as apigenin, naringenin, kaempferol, quercetin-3-O-glucoside and others to benzodiazepine binding sites [149] of different receptors including the GABA-A-receptor [52,132] and adenosine receptors [139], and investigated their anxiolytic potential [149] as a possible mechanism of action in the CNS. Bastianetto et al. report that antioxidant effects are not the only mechanism of flavonoid-mediated protection against neuronal death and show attenuation of $\mathrm{NO}^{\bullet}$-induced activation of protein kinase C (PKC) by G. biloba [12] and resveratrol [13] to be partially involved in the protection against neurotoxicity.

However, the precise mechanisms by which flavonoids exert their neuroprotective actions in vivo and in vitro are presently unclear and it is only recently that experimental evidence is emerging suggesting that the protective properties of these compounds may be mediated via the modulation of signal transduction pathways [178]. For example, accumulating evidence suggests that flavonoids can interact selectively within MAPK signaling cascades in non-neuronal models $[104,107]$. This could have important implications with regard to their possible sites of action in neurons since members of the MAPK family are involved in signaling to neuronal survival, regeneration, and death $[48,136,226]$.

It has been shown recently that pre-treatment with low micromolar concentration of epicatechin and kaempferol strongly protected against oxLDL-induced death in primary striatal neurons [179] involving annexin- $\mathrm{V}$ binding, caspase-3 activation, and DNA-fragmentation [178]. Interestingly, the flavonoid pre-treatments did not prevent the oxLDL-mediated increase in intracellular oxidative stress but potently inhibited the oxLDL-induced activation of JNK, c-Jun and caspase-3. Furthermore, ascorbic acid did not exert strong protection even when used in concentrations 
10 times higher than flavonoids and the in vivo metabolite of epicatechin, $3^{\prime}-O$-methyl-epicatechin, a compound with less than half the hydrogen-donating antioxidant activity of epicatechin [194] was found here to have the same ability to attenuate oxLDL-mediated neuronal death. These findings indicate that flavonoids might exert their neuroprotective effects seemingly independent of their classical hydrogendonating capacity and demonstrate for the first time a possible involvement of flavonoids in neuronal MAPK signaling under oxidative stress. It might be speculated that potential targets of flavonoids modulation of cellular responses to oxidative stress might occur by direct interactions with proteins of signal transduction pathways, by affecting the intracellular calcium homeostasis or influencing mPT. In this context, it is interesting that the chemical structures of various pharmacological inhibitors of intracellular signaling cascades, including the MEK inhibitor PD98059 and the PI3-kinase inhibitor LY294002, are closely related to the basic structure of flavonoids.

As discussed earlier, the mitochondria play a central role in oxidative/nitrosative stress-induced apoptosis and the prevention of $\mathrm{mPT}$ and/or the release of AIF such as cytochrome $c$ may exemplify potent means to counteract apoptotic neurodegeneration. Speculatively, the flavonoid-mediated inhibition of apoptosis might occur by a variety of means: firstly, by blocking the activation of JNK. This might take place upstream of JNK influencing one of many MAPKKK activating proteins involved in transducing signals to JNK. Secondly, at the level of maintaining the calcium homeostasis shown to be implicated in MAPK activation $[60,87,234]$ and NOS activity. Thirdly, flavonoids might modulate the mPT believed to be important in apoptotic cell death by either opening a gateway for cytochrome $c$ release from the mitochondria $[74,202]$ or by activating other mitochondrial-related proapoptotic factors such as DIABLO/smac [72,195]. Inhibitors of the mPTP opening like cyclosporin A bind to cyclophilin $\mathrm{D}$ which is associated with the adenine nucleotide transporter (ANT), part of the multi protein complex of the mPTP [200], and modulate mitochondrial depolarization [229], cytochrome $c$ translocation [230], and cell death [74,230]. On the contrary, mPTP openers such as the ANT-activator atractyloside trigger mPTP opening, cytochrome $c$ release and apoptosis [229,230]. Interestingly, the mPTP possesses a benzodiazepine binding site and the binding of ligands such as PK11195 [36,55] and antagonists like flumazenil [69] have been shown to modulate the mPTP. Since flavonoids have been reported to bind to benzodiazepine binding sites of GABA-A and adenosine receptors [52,132], they might also exert an effect on the mPTP and, therefore, modulate cytochrome $c$ release. In addition flavonoids have been found to bind to ATP-binding sites of proteins [43] such as the mitochondrial ATPase [53], calcium plasma membrane ATPase [10] protein kinase A [164], PKC [117] and topoisomerase [17] all of which must be considered in intracellular responses to oxidative insults. Thus, flavonoids might be able to modulate mitochondrial functions by binding to
ATP binding sits on the ANT, ATPases or others. Indeed, bongkrekic acid an antagonist of the ATP-binding site of the ANT has been shown to prevent $\mathrm{mPT}$ and the early activation of $\mathrm{JNK}$ in $\mathrm{MPP}^{+}$-induced neuronal injury as a model for Parkinson's disease [28].

Overall, flavonoids might influence the release of proapoptotic factors such as cytochrome $c$ from the mitochondrion, thus providing an interesting hypothesis for future investigations.

A different interpretation of potential bioactive effects of flavonoids might be the upregulation of antioxidant enzymes such as SOD, catalase, glutathione peroxidase, and enzymes related to glutathione synthesis. Speculatively, this may occur by two means. Firstly, direct effects on the activity of transcription factors or signaling cascades leading to the transcription of the above enzymes. Secondly, some flavonoids or their oxidation products (phenoxyl radical, quinones) may induce moderate levels of oxidative stress based on their pro-oxidant effects which can induce the upregulation of antioxidant defence enzymes similar to the priming effect of low doses of radiation of low concentrations of hydrogen peroxide. The expression of some enzymes implicated in antioxidant defences such as the enzymes for glutathione synthesis [235] and heme oxygenase [37] exhibit ERK1/2 dependency in the regulation of their expression. Furthermore, the transcription of $\mathrm{Cu} / \mathrm{ZnSOD}$ is regulated by the transcription factor ELK-1 [35] and the promoter for MnSOD expression contain binding sites for Sp1, AP-1, and CREB [35,47], all of which have been linked to regulation by ERK1/2 [34,182].

In addition nitric oxide has been identified as a potent modulator of mitochondrial function, as discussed before. Recent reports demonstrated that the induction of iNOS expression following treatment with LPS or interferon- $\gamma$ [108], as well as the expression of nNOS requires the ERK1/2 signaling pathway, providing a potentially interesting link between MAPK signaling, nitric oxide production, and mitochondrial function. Since epicatechin and kaempferol have been shown to attenuate the oxidative stress-mediated activation of ERK1/2 [178] it remains to be established whether or not these flavonoids are capable of suppressing the production of $\mathrm{NO}^{\bullet}$ in neurons and glial cells in vivo as reported for iNOS in cultured macrophages [99,109,154], and what influences this may have on cellular outcomes of oxidative insults.

Taken together the MAPK signaling cascade might exemplify a possible link between flavonoids and the modulation of cellular responses to oxidative stress. However, this link is circumstantial, speculative, and remains to be further investigated.

With respect to the overall subject concerning the potential use of flavonoids against neurodegeneration during aging or disease, the bioavailability of flavonoids especially, to the target tissues in the CNS, is of fundamental importance. The fact that flavonoids are extensively metabolised in gut and liver leads to questions about the conse- 
quences of such metabolism with regard to their bioactivity. Glucuronidation, which increases the polarity of the compound, might decrease the accessibility of metabolites into cells and tissues. And indeed the data presented here indicate that glycosylated or glucuronidated flavonoids are much less effective compared to their corresponding aglycones. Thus, the loss in bioactivity might be based on the decline of cell accessibility. This is especially important with respect to the blood-brain barrier and entry to the brain. On the other hand, metabolism like $O$-methylation might increase access to cells and tissues since it increases the lipid solubility. Furthermore, the $O$-methylation of the catechol group in the B-ring of flavonoids will change their oxidizability and might, therefore, increase their stability.

Only a very few investigators have studied the influence of metabolism on the bioactivity of flavonoids $[105,137,178,193,194]$, thus most of the effects reported based on in vitro experiments, cannot be extrapolated to in vivo situations. For example, one of the most intensively investigated flavonoids, quercetin, is often just used as the aglycone in cell culture systems and interesting biological activities such as modulation of the multidrug-resistance protein [118], induction of apoptosis [168], inhibition of the expression of nitric oxide synthase and cyclooxygenase [162], protection against oxidative stress [88] and modulation of the calcium homeostasis [209] have been reported. However, in plants and, therefore, also in all plant-derived foods and beverages, quercetin is always present in a glycosylated form which completely alters its bioactivity. If digested the glycosides might be taken up or are cleaved and the released quercetin is metabolised, so that there is almost no free quercetin aglycone in circulation. Thus, the bioactivities observed using the aglycone alone may be very different form the effects of the derivatives of quercetin. It is, therefore, vital for cell culture experiments to analyze, synthesize and investigate the in vivo metabolites of the flavonoid under investigation. Furthermore, the availability of flavonoids to the brain remains to be investigated further. But perhaps the beneficial effects on memory, motoric functions and against age-related cognitive decline reported so far are not exerted directly in the brain but occur in the periphery and reflect subsequently on to the functions of the CNS. It might be that factors like platelet aggregation, vascular tone, hormonal changes, and immune responses mediated by flavonoid intake induce changes in the CNS.

\section{Summary}

MAPK signal transduction pathways are important for the evaluation and translation of oxidative/nitrosative stimuli into specific cellular responses. The role of MAPK signaling in neurodegeneration, in particular with respect to oxidative/nitrosative stress-induced neuronal death, is gradually emerging, implicating the manipulation of these signal transduction pathways as a potential strategy for therapeutic interventions.

The precise mechanisms of the neuroprotection exerted by flavonoids remain to be established. However, it is becoming increasingly clear that the classical hydrogen-donating activity per se is unlikely to be the sole explanation for the biological properties of flavonoids. This is based on the following arguments: firstly, flavonoids are extensively metabolised in vivo resulting in a significant alteration of their hydrogendonating properties as well as their lipophilicity, i.e. accessibility into tissues. Secondly, concentrations present in plasma and tissues as in the brain are lower than those of ascorbate and Vitamin E, compounds that are considered to be antioxidants in vivo. Thirdly, other biological activities of flavonoids/metabolites have been reported including binding to ATP- and benzodiazepam-binding sites and their effects on enzyme activity, components of intracellular signaling and gene expression. The ability of flavonoids to prevent neuronal cell death following oxidative insults might depend on modulation of intracellular signaling cascades, such as the MAPK signal transduction pathway, and their proposed effects on mitochondrial function. To substantiate further a role for flavonoids as neuroprotective agents, advances are needed especially with regard to understanding accessibility to the brain, the identification of precise molecular targets and the confirmation of the proposed role of flavonoids in the complex organization of intracellular signaling.

With regard to $\mathrm{NO}^{\bullet}$, the other manipulator/mediator of cellular responses discussed in this review, the physical, chemical and biological properties of $\mathrm{NO}^{\bullet}$ make this molecule a potent endogenous modulator of signal transduction. The cellular effects of $\mathrm{NO}^{\bullet}$ depend on its intracellular concentration, the redox status of the cell, the presence of other ROS/RNS and on the dynamics of its generation. Interestingly, accumulating data suggest that the regulation of the expression of nitric oxide synthases depends, at least in part, on MAPK signaling, thereby offering a mechanism of cross-talk between components participating in redox-sensitive cellular functions.

Our overall aim was to elucidate the potential, differential effects of dietary flavonoids, on the one hand, and endogenous $\mathrm{NO}^{\bullet}$, on the other hand, as modulators of neurodegeneration, especially with respect to cellular signaling. This should provide stimulating hypotheses for future investigations.

\section{Acknowledgments}

The Biotechnology and Biological Sciences Research Council (BBSRC 18/D14751) and the Guy's and St. Thomas' Charitable Foundation are thanked for financial support for this research. The authors would also like to acknowledge the help of Dr. Gunter Kuhnle in the technical preparation of this manuscript. 


\section{References}

[1] Adler V, Polotskaya A, Wagner F, Kraft AS. Affinity-purified c-Jun amino-terminal protein kinase requires serine/threonine phosphorylation for activity. J Biol Chem 1992;267(24):17001-5.

[2] Adler V, Yin ZM, Fuchs SY, Benezra M, Rosario L, Tew KD, et al. Regulation of JNK signaling by GSTp. EMBO J 1999;18(5):132134.

[3] Alessandrini A, Namura S, Moskowitz MA, Bonventre JV. MEK1 protein kinase inhibition protects against damage resulting from focal cerebral ischemia. Proc Natl Acad Sci USA 1999;96(22):12866-9.

[4] Alexi T, Borlongan CV, Faull RL, Williams CE, Clark RG, Gluckman PD, et al. Neuroprotective strategies for basal ganglia degeneration: Parkinson's and Huntington's diseases. Prog Neurobiol 2000;60(5):409-70.

[5] Allen RG, Tresini M. Oxidative stress and gene regulation. Free Radic Biol Med 2000;28(3):463-99.

[6] Anania FA, Womack L, Jiang M, Saxena NK. Aldehydes potentiate alpha(2)(I) collagen gene activity by JNK in hepatic stellate cells. Free Radic Biol Med 2001;30(8):846-57.

[7] Anderson RF, Amarasinghe C, Fisher LJ, Mak WB, Packer JE. Reduction in free-radical-induced DNA strand breaks and base damage through fast chemical repair by flavonoids. Free Radic Res 2000;33(1):91-103.

[8] Antunes F, Cadenas E. Cellular titration of apoptosis with steady state concentrations of $\mathrm{H}(2) \mathrm{O}(2)$ : submicromolar levels of $\mathrm{H}(2) \mathrm{O}(2)$ induce apoptosis through Fenton chemistry independent of the cellular thiol state. Free Radic Biol Med 2001;30(9):1008-18.

[9] Antunes F, Cadenas E. Estimation of $\mathrm{H}_{2} \mathrm{O}_{2}$ gradients across biomembranes. FEBS Lett 2000;475:121-6.

[10] Barzilai A, Rahamimoff $\mathrm{H}$. Inhibition of $\mathrm{Ca}^{2+}$-transport ATPase from synaptosomal vesicles by flavonoids. Biochim Biophys Acta 1983;730(2):245-54.

[11] Bastianetto S, Ramassamy C, Dore S, Christen Y, Poirier J, Quirion R. The Ginkgo biloba extract (EGb 761) protects hippocampal neurons against cell death induced by beta-amyloid. Eur J Neurosci 2000;12(6):1882-90.

[12] Bastianetto S, Zheng WH, Quirion R. The Ginkgo biloba extract (EGb 761) protects and rescues hippocampal cells against nitric oxide-induced toxicity: involvement of its flavonoid constituents and protein kinase C. J Neurochem 2000;74(6):2268-77.

[13] Bastianetto S, Zheng WH, Quirion R. Neuroprotective abilities of resveratrol and other red wine constituents against nitric oxiderelated toxicity in cultured hippocampal neurons. Br J Pharmacol 2000;131(4):711-20.

[14] Behl C. Alzheimer's disease and oxidative stress: implications for novel therapeutic approaches. Prog Neurobiol 1999;57(3):301-23.

[15] Behrens A, Sibilia M, Wagner EF. Amino-terminal phosphorylation of c-Jun regulates stress-induced apoptosis and cellular proliferation. Nat Genet 1999;21(3):326-9.

[16] Bhat NR, Zhang P, Bhat AN. Cytokine induction of inducible nitric oxide synthase in an oligodendrocyte cell line: role of p38 mitogenactivated protein kinase activation. J Neurochem 1999;72(2):472-8.

[17] Boege F, Straub T, Kehr A, Boesenberg C, Christiansen K, Andersen A, et al. Selected novel flavones inhibit the DNA binding or the DNA religation step of eukaryotic topoisomerase I. J Biol Chem 1996;271(4):2262-70.

[18] Bonni A, Brunet A, West AE, Datta SR, Takasu MA, Greenberg ME. Cell survival promoted by the Ras-MAPK signaling pathway by transcription-dependent and -independent mechanisms. Science 1999;286(5443):1358-62 [see comments].

[19] Bors W, Michel C, Schikora S. Interaction of flavonoids with ascorbate and determination of their univalent redox potentials: a pulse radiolysis study. Free Radic Biol Med 1995;19(1):45-52.

[20] Boyle SP, Dobson VL, Duthie SJ, Kyle JA, Collins AR. Absorption and DNA protective effects of flavonoid glycosides from an onion meal. Eur J Nutr 2000;39(5):213-23.
[21] Brookes PS, Salinas EP, Darley-Usmar K, Eiserich JP, Freeman BA, Darley-Usmar VM, et al. Concentration-dependent effects of nitric oxide on mitochondrial permeability transition and cytochrome $c$ release. J Biol Chem 2000;275(27):20474-9.

[22] Brown JE, Khodr H, Hider RC, Rice-Evans C. Structural dependence of flavonoid interactions with $\mathrm{Cu}^{2+}$ ions: implications for their antioxidant properties. Biochem J 1998;330(Pt 3):1173-8.

[23] Burdon RH. Superoxide and hydrogen peroxide in relation to mammalian cell proliferation. Free Radic Biol Med 1995;18(4):77594.

[24] Buschmann T, Potapova O, Bar-Shira A, Ivanov VN, Fuchs SY, Henderson $\mathrm{S}$, et al. Jun $\mathrm{NH}_{2}$-terminal kinase phosphorylation of p53 on Thr- 81 is important for p53 stabilization and transcriptional activities in response to stress. Mol Cell Biol 2001;21(8):2743-54.

[25] Buschmann T, Yin ZM, Bhoumik A, Ronai Z. Amino-terminalderived JNK fragment alters expression and activity of c-Jun, ATF2, and p53 and increases $\mathrm{H}_{2} \mathrm{O}_{2}$-induced cell death. $\mathrm{J}$ Biol Chem 2000;275(22):16590-6.

[26] Cai J, Jones DP. Superoxide in apoptosis. Mitochondrial generation triggered by cytochrome $c$ loss. J Biol Chem 1998;273(19): 11401-4.

[27] Camandola S, Poli G, Mattson MP. The lipid peroxidation product 4-hydroxy-2,3-nonenal increases AP-1-binding activity through caspase activation in neurons. J Neurochem 2000;74(1):159-68.

[28] Cassarino DS, Halvorsen EM, Swerdlow RH, Abramova NN, Parker Jr WD, Sturgill TW, et al. Interaction among mitochondria, mitogenactivated protein kinases, and nuclear factor-kappaB in cellular models of Parkinson's disease. J Neurochem 2000;74(4):1384-92.

[29] Castelluccio C, Paganga G, Melikian N, Bolwell GP, Pridham $\mathrm{J}$, Sampson J, et al. Antioxidant potential of intermediates in phenylpropanoid metabolism in higher plants. FEBS Lett 1995;368(1):188-92.

[30] Cavigelli M, Dolfi F, Claret FX, Karin M. Induction of cfos expression through JNK-mediated TCF/Elk-1 phosphorylation. EMBO J 1995;14(23):5957-64.

[31] Chan ED, Riches DW. IFN-gamma + LPS induction of iNOS is modulated by ERK, JNK/SAPK, and p38(mapk) in a mouse macrophage cell line. Am J Physiol Cell Physiol 2001;280(3):C44150.

[32] Chan ED, Winston BW, Uh ST, Wynes MW, Rose DM, Riches DW. Evaluation of the role of mitogen-activated protein kinases in the expression of inducible nitric oxide synthase by IFN-gamma and TNF-alpha in mouse macrophages. J Immunol 1999;162:415-22.

[33] Chan FL, Choi HL, Chen ZY, Chan PS, Huang Y. Induction of apoptosis in prostate cancer cell lines by a flavonoid, baicalin. Cancer Lett 2000;160(2):219-28.

[34] Chang L, Karin M. Mammalian MAP kinase signalling cascades. Nature 2001;410(6824):37-40.

[35] Chang MS, Yoo HY, Rho HM. Positive and negative regulatory elements in the upstream region of the rat $\mathrm{Cu} / \mathrm{Zn}$-superoxide dismutase gene. Biochem J 1999;339(Pt 2):335-41.

[36] Chelli B, Falleni A, Salvetti F, Gremigni V, Lucacchini A, Martini C. Peripheral-type benzodiazepine receptor ligands: mitochondrial permeability transition induction in rat cardiac tissue. Biochem Pharmacol 2001;61(6):695-705.

[37] Chen K, Maines MD. Nitric oxide induces heme oxygenase-1 via mitogen-activated protein kinases ERK and p38. Cell Mol Biol 2000;46(3):609-17.

[38] Chen Z, Yuhanna IS, Galcheva-Gargova Z, Karas RH, Mendelsohn ME, Shaul PW. Estrogen receptor alpha mediates the nongenomic activation of endothelial nitric oxide synthase by estrogen. J Clin Invest 1999;103:401-6.

[39] Cho SG, Lee YH, Park HS, Ryoo K, Kang KW, Park J, et al Glutathione $S$-transferase mu modulates the stress-activated signals by suppressing apoptosis signal-regulating kinase 1 . J Biol Chem 2001;276(16):12749-55. 
[40] Choi WS, Yoon SY, Chang II, Choi EJ, Rhim H, Jin BK, et al. Correlation between structure of Bcl-2 and its inhibitory function of JNK and caspase activity in dopaminergic neuronal apoptosis. J Neurochem 2000;74(4):1621-6.

[41] Cleeter MW, Cooper JM, Darley-Usmar VM, Moncada S, Schapira AH. Reversible inhibition of cytochrome $c$ oxidase, the terminal enzyme of the mitochondrial respiratory chain, by nitric oxide. Implications for neurodegenerative diseases. FEBS Lett 1994;345(1):50-4.

[42] Cockle SM, Kimbe S, Hindmarch I. The effects of Gingko biloba extract (LI 1370) supplementation on activities of daily living in free living older volunteers: a questionnare survey. Hum Psychopharm Clin 2000;15:227-35.

[43] Conseil G, Baubichon-Cortay H, Dayan G, Jault JM, Barron D, Di Pietro A. Flavonoids: a class of modulators with bifunctional interactions at vicinal ATP- and steroid-binding sites on mouse Pglycoprotein. Proc Natl Acad Sci USA 1998;95(17):9831-6.

[44] Coyle JT, Puttfarcken P. Oxidative stress, glutamate, and neurodegenerative disorders. Science 1993;262(5134):689-95.

[45] Crow JP, Beckman JS. Reactions between nitric oxide, superoxide, and peroxynitrite: footprints of peroxynitrite in vivo. Adv Pharmacol 1995;34:17-43.

[46] Da Silva J, Pierrat B, Mary JL, Lesslauer W. Blockade of p38 mitogen-activated protein kinase pathways inhibits inducible nitricoxide synthase expression in mouse astrocytes. J Biol Chem 1997;272:28373-80.

[47] Das KC, Lewis-Molock Y, White CW. Activation of NF-kappa B and elevation of MnSOD gene expression by thiol reducing agents in lung adenocarcinoma (A549) cells. Am J Physiol 1995;269(5 Pt 1):L588-602.

[48] Davis RJ. Signal transduction by the JNK group of MAP kinases Cell 2000;109:239-52.

[49] Dawson VL, Dawson TM, London ED, Bredt DS, Snyder SH. Nitric oxide mediates glutamate neurotoxicity in primary cortical cultures. Proc Natl Acad Sci USA 1991;88:6368-71.

[50] de Rijk MC, Breteler MM, den Breeijen JH, Launer LJ, Grobbee DE, van der Meche FG, et al. Dietary antioxidants and Parkinson disease. The Rotterdam Study. Arch Neurol 1997;54(6):762-5.

[51] Deak M, Clifton AD, Lucocq LM, Alessi DR. Mitogen- and stressactivated protein kinase-1 (MSK1) is directly activated by MAPK and SAPK2/p38, and may mediate activation of CREB. EMBO J 1998;17(15):4426-41.

[52] Dekermendjian K, Kahnberg P, Witt MR, Sterner O, Nielsen M, Liljefors T. Structure-activity relationships and molecular modeling analysis of flavonoids binding to the benzodiazepine site of the rat brain GABA(A) receptor complex. J Med Chem 1999;42(21):434350.

[53] Di Pietro A, Godinot C, Bouillant ML, Gautheron DC. Pig heart mitochondrial ATPase: properties of purified and membrane-bound enzyme. Effects of flavonoids. Biochimie 1975;57(8):959-67.

[54] Dimmeler S, Fleming I, Fisslthaler B, Hermann C, Busse R, Zeiher AM. Activation of nitric oxide synthase in endothelial cells by Akt-dependent phosphorylation. Nature 1999;399:601-5.

[55] Donahue RJ, Razmara M, Hoek JB, Knudsen TB. Direct influence of the $\mathrm{p} 53$ tumor suppressor on mitochondrial biogenesis and function. FASEB J 2001;15(3):635-44.

[56] Donovan JL, Bell JR, Kasim-Karakas S, German JB, Walzem RL, Hansen RJ, et al. Catechin is present as metabolites in human plasma after consumption of red wine. J Nutr 1999;129(9):1662-8.

[57] Dore S, Bastianetto S, Kar S, Quirion R. Protective and rescuing abilities of IGF-I and some putative free radical scavengers against beta-amyloid-inducing toxicity in neurons. Ann NY Acad Sci 1999;890:356-64.

[58] Edenharder R, von Petersdorff I, Rauscher R. Antimutagenic effects of flavonoids, chalcones and structurally related compounds on the activity of 2-amino-3-methylimidazo[4,5-f]quinoline (IQ) and other heterocyclic amine mutagens from cooked food. Mutat Res 1993;287(2):261-74.
[59] Eilers A, Whitfield J, Shah B, Spadoni C, Desmond H, Ham J. Direct inhibition of c-Jun $\mathrm{N}$-terminal kinase in sympathetic neurones prevents c-Jun promoter activation and NGF withdrawal-induced death. J Neurochem 2001;76(5):1439-54.

[60] Enslen H, Tokumitsu H, Stork PJ, Davis RJ, Soderling TR. Regulation of mitogen-activated protein kinases by a calcium/ calmodulin-dependent protein kinase cascade. Proc Natl Acad Sci USA 1996;93(20): 10803-8.

[61] Fan MY, Goodwin M, Vu T, Brantley-Finley C, Gaarde WA, Chambers TC. Vinblastine-induced phosphorylation of Bcl-2 and Bcl- $\mathrm{X}_{\mathrm{L}}$ is mediated by JNK and occurs in parallel with inactivation of the Raf-1/MEK/ERK cascade. J Biol Chem 2000;275:29980-5.

[62] Faris M, Latinis KM, Kempiak SJ, Koretzky GA, Nel A. Stressinduced Fas ligand expression in T cells is mediated through a MEK kinase 1-regulated response element in the Fas ligand promoter. Mol Cell Biol 1998;18(9):5414-24.

[63] Ferrer I, Planas AM, Pozas E. Radiation-induced apoptosis in developing rats and kainic acid-induced excitotoxicity in adult rats are associated with distinctive morphological and biochemical c-Jun/AP-1 (N) expression. Neurosci 1997;80(2):449-58 [see comments].

[64] Finkel T, Holbrook NJ. Oxidants, oxidative stress and the biology of ageing. Nature 2000;408(6809):239-47.

[65] Fuchs SY, Adler V, Pincus MR, Ronai Z. MEKK1/JNK signaling stabilizes and activates p53. Proc Natl Acad Sci USA 1998;95(18):10541-6.

[66] Fuchs SY, Dolan L, Davis RJ, Ronai Z. Phosphorylation-dependent targeting of c-Jun ubiquitination by Jun N-kinase. Oncogene 1996;13(7):1531-5.

[67] Fuchs SY, Xie B, Adler V, Fried VA, Davis RJ, Ronai Z. c-Jun $\mathrm{NH} 2$-terminal kinases target the ubiquitination of their associated transcription factors. J Biol Chem 1997;272(51):32163-8.

[68] Fukuto JM. Chemistry of nitric oxide: biologically relevant aspects. Adv Pharmacol 1995;34:1-15.

[69] Galeffi F, Sinnar S, Schwartz-Bloom RD. Diazepam promotes ATP recovery and prevents cytochrome $c$ release in hippocampal slices after in vitro ischemia. J Neurochem 2000;75(3):1242-9.

[70] Garthwaite J, Boulton CL. Nitric oxide signaling in the central nervous system. Annu Rev Physiol 1995;57:683-706.

[71] Go YM, Patel RP, Maland MC, Park H, Beckman JS, Darley-Usmar $\mathrm{VM}$, et al. Evidence for peroxynitrite as a signaling molecule in flow-dependent activation of c-Jun NH(2)-terminal kinase. Am J Physiol 1999;277(4 Pt 2):H1647-53.

[72] Goyal L. Cell death inhibition: keeping caspases in check. Cell 2001;104(6):805-8.

[73] Gramaglia A, Loi GF, Mongioj V, Baronzio GF. Increased survival in brain metastatic patients treated with stereotactic radiotherapy, omega three fatty acids and bioflavonoids. Anticancer Res 1999;19(6C):5583-6.

[74] Green DR, Reed JC. Mitochondria and apoptosis. Science 1998;281:1309-12.

[75] Gupta S, Barrett T, Whitmarsh AJ, Cavanagh J, Sluss HK, Derijard $\mathrm{B}$, et al. Selective interaction of JNK protein kinase isoforms with transcription factors. EMBO J 1996;15(11):2760-70.

[76] Hakem R, Hakem A, Duncan GS, Henderson JT, Woo M, Soengas MS, et al. Differential requirement for caspase 9 in apoptotic pathways in vivo. Cell 1998;94(3):339-52.

[77] Halliwell B. Reactive oxygen species and the central nervous system. J Neurochem 1992;59(5):1609-23.

[78] Harada M, Kan Y, Naoki H, Fukui Y, Kageyama N, Nakai M, et al. Identification of the major antioxidative metabolites in biological fluids of the rat with ingested (+)-catechin and (-)-epicatechin. Biosci Biotechnol Biochem 1999;63(6):973-7.

[79] Heck DE. NO, RSNO, $\mathrm{ONOO}^{-}, \mathrm{NO}^{+}, \mathrm{NOO}$, Nox-dynamic regulation of oxidant scavenging, nitric oxide stores, and cyclic GMP-independent cell signaling. Antioxid Redox Signal 2001; 3(2):249-60 
[80] Hengartner MO. The biochemistry of apoptosis. Nature 2000;407:770-5.

[81] Hertog MG, Feskens EJ, Hollman PC, Katan MB, Kromhout D. Dietary antioxidant flavonoids and risk of coronary heart disease: the Zutphen Elderly Study. Lancet 1993;342(8878):1007-11.

[82] Hirano R, Osakabe N, Iwamoto T, Matsumoto A, Natsume M, Takizawa T, et al. Antioxidant effects of polyphenols in chocolate on low density lipoprotein both in vitro and in vivo. J Nutr Sci Vitaminol 2000;46:199-204.

[83] Hirvonen T, Pietinen P, Virtanen M, Ovaskainen ML, Hakkinen $\mathrm{S}$, Albanes $\mathrm{D}$, et al. Intake of flavonols and flavones and risk of coronary heart disease in male smokers. Epidemiology 2001; 12(1):62-7.

[84] Howlett DR. Association of JNK immunoreactivity with Bamyloid/tau deposits in transgenic mouse brain. Alzheimer Reports 2000:3:11-4.

[85] Ignarro LJ. Haem-dependent activation of guanylate cyclase and cyclic GMP formation by endogenous nitric oxide: a unique transduction mechanism for transcellular signaling. Pharmacol Toxicol 1990;67:1-7.

[86] Inanami O, Watanabe Y, Syuto B, Nakano M, Tsuji M, Kuwabara M. Oral administration of $(-)$ catechin protects against ischemiareperfusion-induced neuronal death in the gerbil. Free Radic Res 1998;29:359-65.

[87] Iordanov MS, Wong J, Newton DL, Rybak SM, Bright RK, Flavell RA, et al. Differential requirement for the stress-activated protein kinase/c-Jun NH(2)-terminal kinase in RNAdamage-induced apoptosis in primary and in immortalized fibroblasts. Mol Cell Biol Res Commun 2000;4(2):122-8.

[88] Ishige K, Schubert D, Sagara Y. Flavonoids protect neuronal cells from oxidative stress by three distinct mechanisms. Free Radic Biol Med 2001;30(4):433-46.

[89] Joseph JA, Denisova N, Fisher D, Bickford P, Prior R, Cao G. Agerelated neurodegeneration and oxidative stress: putative nutritional intervention. Neurol Clin 1998;16(3):747-55.

[90] Joseph JA, Shukitt-Hale B, Denisova NA, Bielinski D, Martin A, McEwen JJ, et al. Reversals of age-related declines in neuronal signal transduction, cognitive, and motor behavioral deficits with blueberry, spinach, or strawberry dietary supplementation. J Neurosci 1999;19(18):8114-21.

[91] Joseph JA, Shukitt-Hale B, Denisova NA, Prior RL, Cao G, Martin A, et al. Long-term dietary strawberry, spinach, or Vitamin E supplementation retards the onset of age-related neuronal signal-transduction and cognitive behavioral deficits. J Neurosci 1998;18(19):8047-55.

[92] Kallunki T, Deng T, Hibi M, Karin M. c-Jun can recruit JNK to phosphorylate dimerization partners via specific docking interactions. Cell 1996;87(5):929-39.

[93] Kan H, Xie Z, Finkel MS. Norepinephrine-stimulated MAP kinase activity enhances cytokine-induced $\mathrm{NO}$ production by rat cardiac myocytes. Am J Physiol 1999;276(1 Pt 2):H47-52.

[94] Kang CD, Jang JH, Kim KW, Lee HJ, Jeong CS, Kim CM, et al. Activation of c-jun $\mathrm{N}$-terminal kinase/stress-activated protein kinase and the decreased ratio of $\mathrm{Bcl}-2$ to $\mathrm{Bax}$ are associated with the auto-oxidized dopamine-induced apoptosis in PC12 cells. Neurosci Lett 1998;256(1):37-40.

[95] Karin M, Liu Z, Zandi E. AP-1 function and regulation. Curr Opin Cell Biol 1997;9(2):240-6.

[96] Keller JN, Hanni KB, Markesbery WR. Oxidized low-density lipoprotein induces neuronal death: implications for calcium, reactive oxygen species, and caspases. J Neurochem 1999;72(6): 2601-9.

[97] Kennedy DO, Scholey AB, Wesnes KA. The dose-dependent cognitive effects of acute administration of Ginkgo biloba to healthy young volunteers. Psychopharmacologia 2000;151(4):416-23.

[98] Kerry N, Rice-Evans C. Inhibition of peroxynitrite-mediated oxidation of dopamine by flavonoid and phenolic antioxidants and their structural relationships. J Neurochem 1999;73(1):247-53.
[99] Kim HK, Cheon BS, Kim YH, Kim SY, Kim HP. Effects of naturally occurring flavonoids on nitric oxide production in the macrophage cell line RAW 264.7 and their structure-activity relationships. Biochem Pharmacol 1999;58(5):759-65.

[100] Kim WG, Mohney RP, Wilson B, Jeohn GH, Liu B, Hong JS Regional difference in susceptibility to lipopolysaccharide-induced neurotoxicity in the rat brain: role of microglia. $\mathrm{J}$ Neurosci 2000;20(16):6309-16.

[101] Kingham PJ, Pocock JM. Microglial apoptosis induced by chromogranin A is mediated by mitochondrial depolarisation and the permeability transition but not by cytochrome $c$ release. J Neurochem 2000;74(4):1452-62.

[102] Kiyono M, Satoh T, Kaziro Y. G protein beta gamma subunitdependent Rac-guanine nucleotide exchange activity of RasGRF1/CDC25(Mm). Proc Natl Acad Sci USA 1999;96(9):4826-31.

[103] Klatt P, Molina EP, De Lacoba MG, Padilla CA, Martinez-Galesteo E, Barcena JA, et al. Redox regulation of c-Jun DNA binding by reversible $S$-glutathiolation. FASEB J 1999;13(12):1481-90.

[104] Kobuchi H, Roy S, Sen CK, Nguyen HG, Packer L. Quercetin inhibits inducible ICAM-1 expression in human endothelial cells through the JNK pathway. Am J Physiol 1999;277(3 Pt 1):C403-11.

[105] Koga T, Meydani M. Effect of plasma metabolites of (+)-catechin and quercetin on monocyte adhesion to human aortic endothelial cells. Am J Clin Nutr 2001;73(5):941-8.

[106] Komatsu M, Hiramatsu M. The efficacy of an antioxidant cocktail on lipid peroxide level and superoxide dismutase activity in aged rat brain and DNA damage in iron-induced epileptogenic foci. Toxicology 2000;148(2/3):143-8.

[107] Kong AN, Yu R, Chen C, Mandlekar S, Primiano T. Signal transduction events elicited by natural products: role of MAPK and caspase pathways in homeostatic response and induction of apoptosis. Arch Pharm Res 2000;23(1):1-16.

[108] Kristof AS, Marks-Konczalik J, Moss J. Mitogen-activated protein kinases mediate activator protein-1-dependent human inducible nitric-oxide synthase promoter activation. J Biol Chem 2001;276(11):8445-52.

[109] Krol W, Czuba ZP, Threadgill MD, Cunningham BD, Pietsz G Inhibition of nitric oxide $\left(\mathrm{NO}^{\bullet}\right)$ production in murine macrophages by flavones. Biochem Pharmacol 1995;50(7):1031-5.

[110] Kuhnle G, Spencer JP, Chowrimootoo G, Schroeter H, Debnam ES, Srai SK, et al. Resveratrol is absorbed in the small intestine as resveratrol glucuronide. Biochem Biophys Res Commun 2000;272(1):212-7.

[111] Kuhnle G, Spencer JP, Schroeter H, Shenoy B, Debnam ES, Srai SK, et al. Epicatechin and catechin are $O$-methylated and glucuronidated in the small intestine. Biochem Biophys Res Commun 2000;277(2):507-12.

[112] Kumari MV, Yoneda T, Hiramatsu M. Effect of "beta CATECHIN" on the life span of senescence accelerated mice (SAM-P8 strain) Biochem Mol Biol Int 1997;41(5):1005-11.

[113] La Grande L, Wang M, Watkins R, Ortiz D, Sanchez ME, Konst $\mathrm{J}$, et al. Protective effects of the flavonoid mixture, sylimarin, on fetal rat brain and liver. J Ethnopharmacol 1995;65:53-61.

[114] Lander HM, Hajjar DP, Hempstead BL, Mirza UA, Chait BT, Campbell S, et al. A molecular redox switch on p21(ras). Structural basis for the nitric oxide-p21(ras) interaction. J Biol Chem 1997;272(7):4323-6.

[115] Lander HM, Ogiste JS, Pearce SF, Levi R, Novogrodsky A. Nitric oxide-stimulated guanine nucleotide exchange on p21ras. J Biol Chem 1995;270(13):7017-20.

[116] Lander HM, Ogiste JS, Teng KK, Novogrodsky A. p2 $1^{\text {ras }}$ as a common signaling target of reactive free radicals and cellular redox stress. J Biol Chem 1995;270(36):21195-8.

[117] Lee SF, Lin JK. Inhibitory effects of phytopolyphenols on TPAinduced transformation, PKC activation, and c-jun expression in mouse fibroblast cells. Nutr Cancer 1997;28(2):177-83. 
[118] Leslie EM, Mao Q, Oleschuk CJ, Deeley RG, Cole SP. Modulation of multidrug resistance protein 1 (MRP1/ABCC1) transport and atpase activities by interaction with dietary flavonoids. Mol Pharmacol 2001;59(5):1171-80.

[119] Levonen AL, Patel RP, Brookes P, Go YM, Jo H, Parthasarathy $\mathrm{S}$, et al. Mechanisms of cell signaling by nitric oxide and peroxynitrite: from mitochondria to MAP kinases. Antioxid Redox Signal 2001;3(2):215-29.

[120] Li P, Nijhawan D, Budihardjo I, Srinivasula SM, Ahmad M, Alnemri $\mathrm{ES}$, et al. Cytochrome $c$ and dATP-dependent formation of Apaf$1 /$ caspase-9 complex initiates an apoptotic protease cascade. Cell 1997;91(4):479-89.

[121] Liberatore GT, Jackson-Lewis V, Vukosavic S, Mandir AS, Vila M, McAuliffe WG, et al. Inducible nitric oxide synthase stimulates dopaminergic neurodegeneration in the MPTP model of Parkinson disease. Nat Med 1999;5(12):1403-9 [see comments].

[122] Lim CP, Cao X. Serine phosphorylation and negative regulation of Stat3 by JNK. J Biol Chem 1999;274(43):31055-61.

[123] Lipton SA, Choi Y-B, Pan Z-H, Lei SZ, Chen H-SV, Sucher $\mathrm{NJ}$, et al. A redox-based mechanism for the neuroprotective and neurodestructive effects of nitric oxide and related nitrosocompounds. Nature 1993;364:626-32.

[124] Liu YF. Expression of polyglutamine-expanded Huntingtin activates the SEK1-JNK pathway and induces apoptosis in a hippocampal neuronal cell line. J Biol Chem 1998;273(44):28873-7.

[125] Logani S, Chen MC, Tran T, Le T, Raffa RB. Actions of Ginkgo biloba related to potential utility for the treatment of conditions involving cerebral hypoxia. Life Sci 2000;67(12):1389-96.

[126] Maroney AC, Finn JP, Bozyczko-Coyne D, O'Kane TM, Neff NT, Tolkovsky AM, et al. CEP-1347 (KT7515), an inhibitor of JNK activation, rescues sympathetic neurons and neuronally differentiated PC12 cells from death evoked by three distinct insults. J Neurochem 1999;73(5):1901-12.

[127] Marshall HE, Merchant K, Stamler JS. Nitrosation and oxidation in the regulation of gene expression. FASEB J 2000;14:1889-900.

[128] Maurer K, Ihl R, Dierks T, Frolich L. Clinical efficacy of Gingko biloba special extract EGb 761 in dementia of the Alzheimer type. J Psychiatr Res 1997;31(6):643-53.

[129] Mazzoni IE, Said FA, Aloyz R, Miller FD, Kaplan D. Ras regulates sympathetic neuron survival by suppressing the p53-mediated cell death pathway. J Neurosci 1999;19(22):9716-27.

[130] McGeer EG, McGeer PL. The importance of inflammatory mechanisms in Alzheimer disease. Exp Gerontol 1998;33(5):371-8.

[131] McGeer PL, McGeer EG. The inflammatory response system of brain: implications for therapy of Alzheimer and other neurodegenerative diseases. Brain Res Rev 1995;21(2):195-218.

[132] Medina JH, Viola H, Wolfman C, Marder M, Wasowski C, Calvo D, et al. Overview-flavonoids: a new family of benzodiazepine receptor ligands. Neurochem Res 1997;22(4):419-25.

[133] Middleton Jr E, Kandaswami C. Effects of flavonoids on immune and inflammatory cell functions. Biochem Pharmacol 1992;43(6):1167-79.

[134] Middleton Jr E, Kandaswami C, Theoharides TC. The effects of plant flavonoids on mammalian cells: implications for inflammation, heart disease, and cancer. Pharmacol Rev 2000;52(4):673-751.

[135] Mielke K, Brecht S, Dorst A, Herdegen T. Activity and expression of JNK1, p38 and ERK kinases, c-Jun N-terminal phosphorylation, and c-jun promoter binding in the adult rat brain following kainateinduced seizures. Neuroscience 1999;91(2):471-83.

[136] Mielke K, Herdegen T. JNK and p38 stresskinases-degenerative effectors of signal-transduction-cascades in the nervous system. Prog Neurobiol 2000;61(1):45-60.

[137] Moon J, Tsushida T, Nakahara K, Terao J. Identification of quercetin 3-O-beta-D-glucuronide as an antioxidative metabolite in rat plasma after oral administration of quercetin. Free Radic Biol Med 2001;30(11):1274-85.
[138] Morel I, Cillard P, Cillard J. Flavonoid-metal interactions in biological systems. In: Rice-Evans C, Packer L, editors. Flavonoids in health and disease, vol. I. New York: Marcel Dekker, 1998. p. $163-77$.

[139] Moro S, van Rhee AM, Sanders LH, Jacobson KA. Flavonoid derivatives as adenosine receptor antagonists: a comparison of the hypothetical receptor binding site based on a comparative molecular field analysis model. J Med Chem 1998;41(1):46-52.

[140] Murray B, Alessandrini A, Cole AJ, Yee AG, Furshpan EJ. Inhibition of the p44/42 MAP kinase pathway protects hippocampal neurons in a cell-culture model of seizure activity. Proc Natl Acad Sci USA 1998;95(20):11975-80.

[141] Nicholls DG, Ward MW. Mitochondrial membrane potential and neuronal glutamate excitotoxicity: mortality and millivolts. Trends Neurosci 2000;23:166-74.

[142] Nimnual AS, Yatsula BA, Bar-Sagi D. Coupling of Ras and Rac guanosine triphosphatases through the Ras exchanger Sos. Science 1998;279(5350):560-3.

[143] Nishikawa T, Edelstein D, Du XL, Yamagishi S, Matsumura $\mathrm{T}$, Kaneda $\mathrm{Y}$, et al. Normalizing mitochondrial superoxide production blocks three pathways of hyperglycaemic damage. Nature 2000;404:787-90.

[144] Oda K, Arakawa H, Tanaka T, Matsuda K, Tanikawa C, Mori T, et al. p53AIP1, a potential mediator of p53-dependent apoptosis, and its regulation by Ser-46-phosphorylated p53. Cell 2000;102(6):84962.

[145] Oguro T, Hayashi M, Nakajo S, Numazawa S, Yoshida T. The expression of heme oxygenase-1 gene responded to oxidative stress produced by phorone, a glutathione depletor, in the rat liver; the relevance to activation of c-jun N-terminal kinase. J Pharmacol Exp Ther 1998;287(2):773-8.

[146] Oken BS, Storzbach DM, Kaye JA. The efficacy of Ginkgo biloba on cognitive function in Alzheimer disease. Arch Neurol 1998;55(11):1409-15.

[147] Okushio K, Suzuki M, Matsumoto N, Nanjo F, Hara Y. Identification of (-)-epicatechin metabolites and their metabolic fate in the rat. Drug Metab Dispos 1999;27(2):309-16.

[148] Oliver CN, Starke-Reed PE, Stadtman ER, Liu GJ, Carney JM, Floyd RA. Oxidative damage to brain proteins, loss of glutamine synthetase activity, and production of free radicals during ischemia/reperfusion-induced injury to gerbil brain. Proc Natl Acad Sci USA 1990;87(13):5144-7.

[149] Paladini AC, Marder M, Viola H, Wolfman C, Wasowski C, Medina $\mathrm{JH}$. Flavonoids and the central nervous system: from forgotten factors to potent anxiolytic compounds. J Pharm Pharmacol 1999;51(5):519-26.

[150] Pannala AS, Razaq R, Halliwell B, Singh S, Rice-Evans C. Inhibition of peroxynitrite dependent tyrosine nitration by hydroxycinnamates: nitration or electron donation? Free Radic Biol Med 1998;24(4):594-606.

[151] Pannala AS, Rice-Evans C, Halliwell B, Singh S. Inhibition of peroxynitrite-mediated tyrosine nitration by catechin polyphenols. Biochem Biophys Res Commun 1997;232(1):164-8.

[152] Park HS, Huh SH, Kim MS, Lee SH, Choi EJ. Nitric oxide negatively regulates c-Jun $\mathrm{N}$-terminal kinase/stress-activated protein kinase by means of $S$-nitrosylation. Proc Natl Acad Sci USA 2000;97(26):14382-7 [see comments].

[153] Park HS, Park E, Kim MS, Ahn K, Kim IY, Choi EJ. Selenite inhibits the c-Jun N-terminal kinase/stress-activated protein kinase (JNK/SAPK) through a thiol redox mechanism. J Biol Chem 2000;275(4):2527-31.

[154] Park YC, Rimbach G, Saliou C, Valacchi G, Packer L. Activity of monomeric, dimeric, and trimeric flavonoids on NO production, TNF-alpha secretion, and NF-kappaB-dependent gene expression in RAW 264.7 macrophages. FEBS Lett 2000;465(2/3):93-7.

[155] Peng HW, Cheng FC, Huang YT, Chen CF, Tsai TH. Determination of naringenin and its glucuronide conjugate in rat plasma and brain 
tissue by high-performance liquid chromatography. J Chromatogr B Biomed Sci Appl 1998;714(2):369-74.

[156] Perkinton MS, Sihra TS, Williams RJ. $\mathrm{Ca}(2+)$-permeable AMPA receptors induce phosphorylation of cAMP response elementbinding protein through a phosphatidylinositol 3-kinase-dependent stimulation of the mitogen-activated protein kinase signaling cascade in neurons. J Neurosci 1999;19(14):5861-74.

[157] Poderoso JJ, Carreras MC, Lisdero CL, Riobo N, Schopfer F, Boveris A. Nitric oxide inhibits electron transfer and increases superoxide radical production in rat heart mitochondria and submitochondrial particles. Arch Biochem Biophys 1996;328(1):8592.

[158] Poderoso JJ, Carreras MC, Schopfer F, Lisdero CL, Riobo NA, Giulivi $\mathrm{C}$, et al. The reaction of nitric oxide with ubiquinol: kinetic properties and biological significance. Free Radic Biol Med 1999;26(7/8):925-35.

[159] Poderoso JJ, Lisdero CL, Schopfer F, Riobo N, Carreras MC, Cadenas $\mathrm{E}$, et al. The regulation of mitochondrial oxygen uptake by redox reactions involving nitric oxide and ubiquinol. J Biol Chem 1999;274(53):37709-16.

[160] Pulverer BJ, Kyriakis JM, Avruch J, Nikolakaki E, Woodgett JR. Phosphorylation of c-jun mediated by MAP kinases. Nature 1991;353(6345):670-4.

[161] Quinn J, Kaye J. The neurology of aging. Neurologist 2001;7:98112.

[162] Raso GM, Meli R, Di Carlo G, Pacilio M, Di Carlo R. Inhibition of inducible nitric oxide synthase and cyclooxygenase- 2 expression by flavonoids in macrophage J774A.1. Life Sci 2001;68(8):921-31.

[163] Ray SD, Wong V, Rinkovsky A, Bagchi M, Raje RR, Bagchi D. Unique organoprotective properties of a novel IH636 grape seed proanthocyanidin extract on cadmium chloride-induced nephrotoxicity, dimethylnitrosamin (DMN)-induced splenotoxicity and MOCAP-induced neurotoxicity in mice. Res Commun Mol Pathol Pharmcol 2000;107:105-28.

[164] Revuelta MP, Cantabrana B, Hidalgo A. Depolarization-dependent effect of flavonoids in rat uterine smooth muscle contraction elicited by $\mathrm{CaCl}_{2}$. Gen Pharmacol 1997;29(5):847-57.

[165] Reynolds CH, Utton MA, Gibb GM, Yates A, Anderton BH. Stressactivated protein kinase/c-jun $\mathrm{N}$-terminal kinase phosphorylates tau protein. J Neurochem 1997;68(4):1736-44.

[166] Rice-Evans C, Miller NJ, Paganga G. Structure-antioxidant activity relationships of flavonoids and phenolic acids. Free Radic Biol Med 1996;20(7):933-56.

[167] Rogatsky I, Logan SK, Garabedian MJ. Antagonism of glucocorticoid receptor transcriptional activation by the c-Jun Nterminal kinase. Proc Natl Acad Sci USA 1998;95(5):2050-5.

[168] Rong Y, Yang EB, Zhang K, Mack P. Quercetin-induced apoptosis in the monoblastoid cell line U937 in vitro and the regulation of heat shock proteins expression. Anticancer Res 2000;20(6B):4339-45.

[169] Russo A, Acquaviva R, Campisi A, Sorrenti V, Di Giacomo C, Virgata G, et al. Bioflavonoids as antiradicals, antioxidants and DNA cleavage protectors. Cell Biol Toxicol 2000;16(2):91-8.

[170] Saitoh M, Nishitoh H, Fujii M, Takeda K, Tobiume K, Sawada $\mathrm{Y}$, et al. Mammalian thioredoxin is a direct inhibitor of apoptosis signal-regulating kinase (ASK) 1. EMBO J 1998;17(9):2596-606.

[171] Salah N, Miller NJ, Paganga G, Tijburg L, Bolwell GP, RiceEvans C. Polyphenolic flavanols as scavengers of aqueous phase radicals and as chain-breaking antioxidants. Arch Biochem Biophys 1995;322(2):339-46.

[172] Samanta S, Perkinton MS, Morgan M, Williams RJ. Hydrogen peroxide enhances signal-responsive arachidonic acid release from neurons: role of mitogen-activated protein kinase. J Neurochem 1998;70(5):2082-90.

[173] Saporito MS, Thomas BA, Scott RW. MPTP activates c-Jun NH(2)terminal kinase (JNK) and its upstream regulatory kinase MKK4 in nigrostriatal neurons in vivo. J Neurochem 2000;75(3):1200-8.
[174] Sata M, Walsh K. Endothelial cell apoptosis induced by oxidized LDL is associated with the down-regulation of the cellular caspase inhibitor FLIP. J Biol Chem 1998;273(50):33103-6.

[175] Satoh T, Nakatsuka D, Watanabe Y, Nagata I, Kikuchi H, Namura S. Neuroprotection by MAPK/ERK kinase inhibition with U0126 against oxidative stress in a mouse neuronal cell line and rat primary cultured cortical neurons. Neurosci Lett 2000;288(2):163-6.

[176] Schaeffer HF, Weber MJ. Mitogen-activated protein kinase: specific messages from ubiquitous messengers. Mol Cell Biol 1999;19:2435-44.

[177] Schonhoff CM, Bulseco DA, Brancho DM, Parada LF, Ross AH The Ras-ERK pathway is required for the induction of neuronal nitric oxide synthase in differentiating PC12 cells. J Neurochem 2001;78:631-9.

[178] Schroeter H, Spencer JPE, Rice-Evans C, Williams RJ. Flavonoids protect neurones from oxidized low-density lipoprotein-induced apoptosis involving JNK, c-jun and caspase-3. Biochem J 2001;358:547-57.

[179] Schroeter H, Williams RJ, Matin R, Iversen L, Rice-Evans C. Phenolic antioxidants attenuate neuronal cell death following uptake of oxidized low-density lipoprotein. Free Radic Biol Med 2000;29(12):1222-33.

[180] Schwarzschild MA, Cole RL, Hyman SE. Glutamate, but not dopamine, stimulates stress-activated protein kinase and AP1-mediated transcription in striatal neurons. J Neurosci 1997; 17(10):3455-66.

[181] Seo SJ, Kim HT, Cho G, Rho HM, Jung G. Sp1 and C/EBP-related factor regulate the transcription of human $\mathrm{Cu} / \mathrm{Zn}$ SOD gene. Gene 1996;178(1/2):177-85.

[182] Sgambato V, Pages C, Rogard M, Besson MJ, Caboche J. Extracellular signal-regulated kinase (ERK) controls immediate early gene induction on corticostriatal stimulation. J Neurosci 1998;18(21):8814-25.

[183] Shiah SG, Chuang SE, Kuo ML. Involvement of Asp-Glu-Val-Aspdirected, caspase-mediated mitogen-activated protein kinase kinase 1 Cleavage, c-Jun N-terminal kinase activation, and subsequent Bcl2 phosphorylation for paclitaxel-induced apoptosis in HL-60 cells. Mol Pharmacol 2001;59(2):254-62.

[184] Shimoi K, Okada H, Furugori M, Goda T, Takase S, Suzuki M, et al. Intestinal absorption of luteolin and luteolin 7-O-beta-glucoside in rats and humans. FEBS Lett 1998;438(3):220-4.

[185] Shimoke K, Yamagishi S, Yamada M, Ikeuchi T, Hatanaka H Inhibition of phosphatidylinositol 3-kinase activity elevates c-Jun Nterminal kinase activity in apoptosis of cultured cerebellar granule neurons. Brain Res Dev Brain Res 1999;112(2):245-53.

[186] Shin-Ya K, Kunigami T, Kim JS, Seto H. Protective effect of catechin against beta-amyloid toxicity in hippocampal neurons and PC12 cells. J Neurochem 1997;69:S42-52.

[187] Shutenko Z, Henry Y, Pinard E, Seylaz J, Potier P, Berthet F, et al. Influence of the antioxidant quercetin in vivo on the level of nitric oxide determined by electron paramagnetic resonance in rat brain during global ischemia and reperfusion. Biochem Pharmacol 1999;57(2):199-208.

[188] Sichel G, Corsaro C, Scalia M, Di Bilio AJ, Bonomo RP. In vitro scavenger activity of some flavonoids and melanins against $\mathrm{O}_{2}{ }^{\bullet-}$. Free Radic Biol Med 1991;11(1):1-8.

[189] Singh K, Balligand JL, Fischer TA, Smith TW, Kelly RA. Regulation of cytokine-inducible nitric oxide synthase in cardiac myocytes and microvascular endothelial cells. Role of extracellular signalregulated kinases 1 and 2 (ERK1/ERK2) and STAT1 alpha. J Biol Chem 1996;271(2):1111-7.

[190] So HS, Park RK, Kim MS, Lee SR, Jung BH, Chung SY, et al. Nitric oxide inhibits c-Jun N-terminal kinase 2 (JNK2) via $S$ nitrosylation. Biochem Biophys Res Commun 1998;247(3):809-13.

[191] Soh Y, Jeong KS, Lee IJ, Bae MA, Kim YC, Song BJ. Selective activation of the c-Jun $\mathrm{N}$-terminal protein kinase pathway during 4-hydroxynonenal-induced apoptosis of PC12 cells. Mol Pharmacol 2000;58(3):535-41. 
[192] Spencer JP, Chowrimootoo G, Choudhury R, Debnam ES, Srai SK, Rice-Evans C. The small intestine can both absorb and glucuronidate luminal flavonoids. FEBS Lett 1999;458(2):224-30.

[193] Spencer JP, Schroeter H, Crossthwaithe AJ, Kuhnle G, Williams $\mathrm{RJ}$, Rice-Evans C. Contrasting influences of glucuronidation and $O$ methylation of epicatechin on hydrogen peroxide-induced cell death in neurons and fibroblasts. Free Radic Biol Med 2001;31(9):113946.

[194] Spencer JP, Schroeter H, Kuhnle G, Srai SK, Tyrrell RM, Hahn U, et al. Epicatechin and its in vivo metabolite, $3^{\prime}$-O-methyl epicatechin, protect human fibroblasts from oxidative-stress-induced cell death involving caspase-3 activation. Biochem J 2001;354(Pt 3):493-500.

[195] Srinivasula SM, Hegde R, Saleh A, Datta P, Shiozaki E, Chai $\mathrm{J}$, et al. A conserved XIAP-interaction motif in caspase-9 and Smac/DIABLO regulates caspase activity and apoptosis. Nature 2001;410(6824):112-6.

[196] Stanciu M, Wang Y, Kentor R, Burke N, Watkins S, Kress G, et al. Persistent activation of ERK contributes to glutamate-induced oxidative toxicity in a neuronal cell line and primary cortical neuron cultures. J Biol Chem 2000;275(16):12200-6.

[197] Sturgill TW, Ray LB, Erikson E, Maller JL. Insulin-stimulated MAP-2 kinase phosphorylates and activates ribosomal protein S6 kinase II. Nature 1988;334(6184):715-8.

[198] Suganuma M, Okabe S, Oniyama M, Tada Y, Ito H, Fujiki H. Wide distribution of $\left[{ }^{3} \mathrm{H}\right](-)$-epigallocatechin gallate, a cancer preventive tea polyphenol, in mouse tissue. Carcinogenesis 1998;19(10): $1771-6$.

[199] Sun GY, Xia J, Draczynska-Lusiak B, Simonyi A, Sun AY. Grape polyphenols protect neurodegenerative changes induced by chronic ethanol administration. Neuroreport 1999;10(1):93-6.

[200] Tafani M, Schneider TG, Pastorino JG, Farber JL. Cytochrome $c$ dependent activation of caspase- 3 by tumor necrosis factor requires induction of the mitochondrial permeability transition. Am J Pathol 2000;156(6):2111-21.

[201] Takekawa M, Saito H. A family of stress-inducible GADD45-like proteins mediate activation of the stress-responsive MTK1/MEKK4 MAPKKK. Cell 1998;95(4):521-30.

[202] Tatton WG, Olanow CW. Apoptosis in neurodegenerative diseases: the role of mitochondria. Biochim Biophys Acta 1999;1410:195213.

[203] Tournaire C, Croux S, Maurette MT, Beck I, Hocquaux M, Braun AM, et al. Antioxidant activity of flavonoids: efficiency of singlet oxygen (1 delta g) quenching. J Photochem Photobiol B 1993;19(3):205-15

[204] Tournier C, Hess P, Yang DD, Xu J, Turner TK, Nimnual A, et al Requirement of JNK for stress-induced activation of the cytochrome $c$-mediated death pathway. Science 2000;288(5467):870-4

[205] Troy CM, Rabacchi SA, Xu Z, Maroney AC, Connors TJ, Shelanski ML, et al. Beta-amyloid-induced neuronal apoptosis requires c-Jun N-terminal kinase activation. J Neurochem 2001;77(1):157-64.

[206] Tsai TH, Chen YF. Determination of unbound hesperetin in rat blood and brain by microdialysis coupled microbore liquid chromatography. J Food Drug Anal 2000;8:331-6.

[207] Turkson J, Bowman T, Adnane J, Zhang Y, Djeu JY, Sekharam $\mathrm{M}$, et al. Requirement for Ras/Rac1-mediated p38 and c-Jun Nterminal kinase signaling in Stat3 transcriptional activity induced by the Src oncoprotein. Mol Cell Biol 1999;19(11):7519-28.

[208] van Dongen MCJM, van Rossum E, Kessels AGH, Sielhorst HJG, Knipschild PG. The efficacy of ginko for elderly people with dementia and age-associated memory impairment: new results of a randomised clinical trial. J Am Geriatr Soc 2000;48:1183-94.

[209] Wang H, Joseph JA. Structure-activity relationships of quercetin in antagonizing hydrogen peroxide-induced calcium dysregulation in PC12 cells. Free Radic Biol Med 1999;27(5/6):683-94.

[210] Wang X, Martindale JL, Liu Y, Holbrook NJ. The cellular response to oxidative stress: influences of mitogen-activated protein kinase signalling pathways on cell survival. Biochem J 1998;333(Pt 2):291300
[211] Watanabe CM, Wolffram S, Ader P, Rimbach G, Packer L, Maguire $\mathrm{JJ}$, et al. The in vivo neuromodulatory effects of the herbal medicine ginkgo biloba. Proc Natl Acad Sci USA 2001;98(12):6577-80.

[212] Wenzel U, Kuntz S, Brendel MD, Daniel H. Dietary flavone is a potent apoptosis inducer in human colon carcinoma cells. Cancer Res 2000;60(14):3823-31.

[213] Wesnes KA, Ward T, McGinty A, Petrini O. The memory enhancing effects of a Ginkgo biloba/Panax ginseng combination in healthy middle-aged volunteers. Psychopharmacologia 2000;152(4):353-61.

[214] Whitfield J, Neame SJ, Paquet L, Bernard O, Ham J. Dominantnegative c-Jun promotes neuronal survival by reducing BIM expression and inhibiting mitochondrial cytochrome $c$ release. Neuron 2001;29(3):629-43.

[215] Whitmarsh AJ, Davis RJ. Transcription factor AP-1 regulation by mitogen-activated protein kinase signal transduction pathways. J Mol Med 1996;74(10):589-607.

[216] Winter JC. The effects of an extract of Ginkgo biloba, EGb 761, on cognitive behavior and longevity in the rat. Physiol Behav 1998;63(3):425-33.

[217] Woo M, Hakem R, Soengas MS, Duncan GS, Shahinian A, Kagi D, et al. Essential contribution of caspase 3/CPP32 to apoptosis and its associated nuclear changes. Genes Dev 1998;12(6):806-19.

[218] Xia Z, Dickens M, Raingeaud J, Davis RJ, Greenberg ME. Opposing effects of ERK and JNK-p38 MAP kinases on apoptosis. Science 1995;270:1326-31.

[219] Yamagishi M, Osakab N, Takizawa T, Osawa T. Cacao liquor polyphenols reduce oxidative stress without maintaining alphatocopherol levels in rats fed a Vitamin E-deficient diet. Lipids 2001;36(1):67-71.

[220] Yamamoto K, Ichijo H, Korsmeyer SJ. BCL-2 is phosphorylated and inactivated by an ASK1/Jun N-terminal protein kinase pathway normally activated at G(2)/M. Mol Cell Biol 1999;19(12):8469-78.

[221] Yamashita N, Kawanishi S. Distinct mechanisms of DNA damage in apoptosis induced by quercetin and luteolin. Free Radic Res 2000;33(5):623-33.

[222] Yang DD, Kuan CY, Whitmarsh AJ, Rincon M, Zheng TS, Davis RJ, et al. Absence of excitotoxicity-induced apoptosis in the hippocampus of mice lacking the Jnk3 gene. Nature 1997; 389(6653):865-70.

[223] Yao Z, Drieu K, Papadopoulos V. The Ginkgo biloba extract EGb 761 rescues the PC12 neuronal cells from beta-amyloid-induced cell death by inhibiting the formation of beta-amyloid-derived diffusible neurotoxic ligands. Brain Res 2001;889(1/2):181-90.

[224] Yin ZM, Ivanov VN, Habelhah H, Tew K, Ronai Z. Glutathione $S$-transferase $\mathrm{p}$ elicits protection against $\mathrm{H}_{2} \mathrm{O}_{2}$-induced cell death via coordinated regulation of stress kinases. Cancer Res 2000;60(15):4053-7.

[225] Yin ZM, Liu AH, Jiang Y. Glutathione $S$-transferase pi protects serum depletion-induced cell death by inhibiting ASK1-MKK7JNK pathway in the 293 cells. Acta Biochim Biophys Sinica 2001;33:185-90.

[226] Yuan J, Yankner BA. Apoptosis in the nervous system. Nature 2000;407(6805):802-9.

[227] Yule DI, Kim ET, Williams JA. Tyrosine kinase inhibitors attenuate "capacitative" $\mathrm{Ca}^{2+}$ influx in rat pancreatic acinar cells. Biochem Biophys Res Commun 1994;202(3):1697-704.

[228] Yun HY, Gonzalez-Zulueta M, Dawson VL, Dawson TM. Nitric oxide mediates $N$-methyl-D-aspartate receptor-induced activation of p21ras. Proc Natl Acad Sci USA 1998;95:5773-8.

[229] Zamzami N, Marchetti P, Castedo M, Hirsch T, Susin SA, Masse $\mathrm{B}$, et al. Inhibitors of permeability transition interfere with the disruption of the mitochondrial transmembrane potential during apoptosis. FEBS Lett 1996;384(1):53-7.

[230] Zamzami N, Susin SA, Marchetti P, Hirsch T, Gomez-Monterrey I, Castedo M, et al. Mitochondrial control of nuclear apoptosis. J Exp Med 1996;183(4):1533-44. 
[231] Zhang Y, Dawson VL, Dawson TM. Oxidative stress and genetics in the pathogenesis of Parkinson's disease. Neurobiol Dis 2000;7(4):240-50.

[232] Zhang Y, Zhou L, Miller CA. A splicing variant of a death domain protein that is regulated by a mitogen-activated kinase is a substrate for c-Jun N-terminal kinase in the human central nervous system. Proc Natl Acad Sci USA 1998;95(5):2586-91.

[233] Zheng J, Bird IM, Melsaether AN, Magness RR. Activation of the mitogen-activated protein kinase cascade is necessary but not sufficient for basic fibroblast growth factor- and epidermal growth factor-stimulated expression of endothelial nitric oxide synthase in ovine fetoplacental artery endothelial cells. Endocrinology 1999;140:1399-407.

[234] Zippel R, Balestrini M, Lomazzi M, Sturani E. Calcium and calmodulin are essential for Ras-GRF1-mediated activation of the Ras pathway by lysophosphatidic acid. Exp Cell Res 2000; 258(2):403-8.

[235] Zipper LM, Mulcahy RT. Inhibition of ERK and p38 MAP kinases inhibits binding of Nrf2 and induction of GCS genes. Biochem Biophys Res Commun 2000;278(2):484-92. 